\title{
THE STRUCTURE AND MODE OF LIFE OF THE PYRAMIDELLIDAE, PARASITIC OPISTHOBRANCHS
}

\author{
By V. Fretter, Ph.D. and A. Graham, D.Sc. \\ From the Department of Zoology, Birkbeck College, University of London
}

(Text-figs. I-I2)

\begin{tabular}{|c|c|c|c|c|c|c|c|c|}
\hline & & & & & & & & \\
\hline Introductio & . & & & & & & & 493 \\
\hline External fe: & & & & & & & & 494 \\
\hline The alimen & y canal & & & & & & & 500 \\
\hline The vascul & system & & & & & & & 510 \\
\hline The nervou & ystem & & & & & & & 512 \\
\hline Reproducti & & & & & & & & 515 \\
\hline The proces & f feeding & & & & & & & 519 \\
\hline Discussion & . & & & & & & & $52 \mathrm{I}$ \\
\hline Summar & . & & & & & & & 529 \\
\hline References & 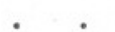 & & & & & & & $53 \mathrm{I}$ \\
\hline
\end{tabular}

\section{INTRODUCTION}

The family Pyramidellidae makes a brave show in fauna lists and similar publications: Winckworth (1932) includes at least forty-one species in his list of British marine molluscs, and Ankel (1936) mentions twenty-seven in the fauna of the North and Baltic Seas. Of the thirty-nine different species, however, of which descriptions are given by Jeffreys (1867), one-third are identified only in respect of their shell characters and nothing at all is said of the appearance of the soft parts of the mollusc; while many volumes, such as the fauna list of the Marine Biological Association (I93I), enter their records of species of Odostomia as 'dead shells only'. It is thus largely true that the pyramidellids are a conchologist's group and that a marine naturalist of considerable experience may not have set eyes upon a member of that family. This is to some extent explained by the fact that all the Pyramidellidae are small, not to say minute, and are not conspicuously coloured, and by the fact that many of them are not particularly common. But one other factor which contributes largely to the general obscurity surrounding this group of gastropods is that each species appears to have its own extremely specialized habitat, and in ignorance of this collecting will not produce any specimens of that particular sort. It has long been known that one species, Odostomia eulimoides Hanley, is to be found 'chiefly (if not only) on the ears of Chlamys opercularis and Pecten maximus', in Jeffreys's words, and this habit of restricting its occurrence to 
one special location appears to be a characteristic of every species of the family. Each one lives in definite relationship to another animal, usually a sedentary polychaete or mollusc, and, presumably, were one to know the particular animal in relation to which each species lives, one could then search for the pyramidellids with fair measure of success. This habit has long been known for a few species-since Jeffreys's time (1867) for Odostomia eulimoides, and since I9I4 for O. scalaris Macgillivray (=rissoides Hanley), when Pelseneer (1914) described this species as living in the neighbourhood of, or actually on, the shell of Mytilus edulis. It was also known as a result of work by Pelseneer (1914), Ankel (1938), and Rasmussen (1944) that these molluscs probably fed on the animals on which, or in the neighbourhood of which, they dwelt, but the details of the feeding process and of the alimentary system were not known. All that appeared certain was that the Pyramidellidae possessed no radula, for which reason Thiele (1929) classified them in the stirps Aglossa of his order Mesogastropoda.

That this classification might not be accurate was first indicated by Thorson (1946), commenting on Lebour's description (1932) of the larvae of Odostomia, which she claimed were unmistakably recognizable by reason of their sinistral shell, which in many species persists throughout life on top of the dextral adult shell. This sinistral larval shell, according to Thorson (I946), is regularly found in the larvae of opisthobranchs, and on this basis he suggests, reviving the much older ideas of Mørch (I865), that the Pyramidellidae are, if not actually opisthobranchs, very closely allied to them. This, however, has been denied by Pelseneer (I899).

The work described in the following pages, carried out at the marine laboratories at Plymouth and Cullercoats as well as in London, shows how the gut of Odostomia species is built and functions, describes the habitat and feeding of a number of different species, the main plan of the mantle cavity, nervous and reproductive systems, the breeding habits and veligers, and concludes, on the basis of this, that the Pyramidellidae should in fact be classified along with the opisthobranchs.

We wish to record our thanks to Mr F. S. Russell, F.R.S., and to Dr H. O. Bull for the facilities provided at Plymouth and Cullercoats respectively, to $\mathrm{Mr}$ R. Winckworth for checking identifications, and to Birkbeck College for a grant.

The following description, unless otherwise stated, applies to the genus Odostomia and to the genus Chrysallida.

\section{EXTERNAL FeATURES}

The Pyramidellidae are all small animals and, so far as external appearances are concerned, they look like any typical monotocardian prosobranch in that the visceral hump is large, wound in a dextral spiral, and enclosed in a stout, 
calcareous shell into which head and foot may be completely withdrawn when the animal is disturbed. The mantle cavity is like that of any prosobranch, too, facing anteriorly and opening to the exterior over the head and almost equally to left and right. There is no clear tendency for the mantle to extend beyond the mouth of the shell except at one point on the right, where it is produced into a short spoon-shaped process.

The foot is short, with a creeping sole, broad anteriorly and tapering posteriorly where, dorsally, it carries a lightly coloured operculum, which sends several tooth-like processes some distance into the flesh of the foot as if to provide greater anchorage for the columellar muscle. Along the mid-ventral line of the sole posteriorly there is a deep longitudinal groove and at the anterior end, which is drawn out laterally into slight points, lies the mouth of the pedal mucous gland, which is well developed, not only filling the central part of the foot with mucous cells but thrusting further lobes into the head, where they lie around the front end of the alimentary canal and the nerve ring. The lateral surfaces of the foot show no outgrowths of any kind.

The foot is covered with a columnar epithelium, strongly ciliated over the entire sole, but with only scattered ciliated cells over the remainder of the surface. Under the epithelium lie large numbers of gland cells, the secretion of which is not mucous. These are spherical in shape, $20 \mu$ in diameter, and they lie in the connective tissue of the foot. Their contents are finely granular and they are discharged by ducts passing between the epithelial cells. In two special areas a second type of gland cell occurs, packed together so as to produce a lateral glandular streak on either side of the foot parallel to the edge of the sole, but placed a little more dorsally, in the same position as described by Yonge (1947) for Patella. The cells (Fig. 2, GC) here are also spherical and lie in the subepithelial connective tissue, opening to the exterior by ducts running between the epithelial cells, but their contents consist of large numbers of spherules which stain strongly with basic stains when ready to be discharged. Frequently smaller granulations $(\mathrm{G})$ lie at the centre of the spherules. A basketwork of muscles (MS) lies around each cell, the fibres running from under the epithelium to end in vertical bundles of muscle (DMF) deeper in the foot, and it seems probable that the contents of the gland cells are squeezed out through the ducts by contraction of this muscular network. In the epithelium through which the cells of the lateral glandular streak open lie scattered cells (CC) bearing bundles of long cilia $(30 \mu)$. These are perhaps sensory in nature as similar ones appear regularly in the epithelium which covers the surface of the cephalic tentacles (see below), and their presence would suggest that the lateral glandular streak is some kind of sensory organ.

From the opening of the pedal mucous gland the anterior dorsal surface of the foot curves upwards and backwards on to the head, but before that part of the body is reached the foot projects outwards into a thin fold running transversely from one side of the body to the other and slightly indented in the 


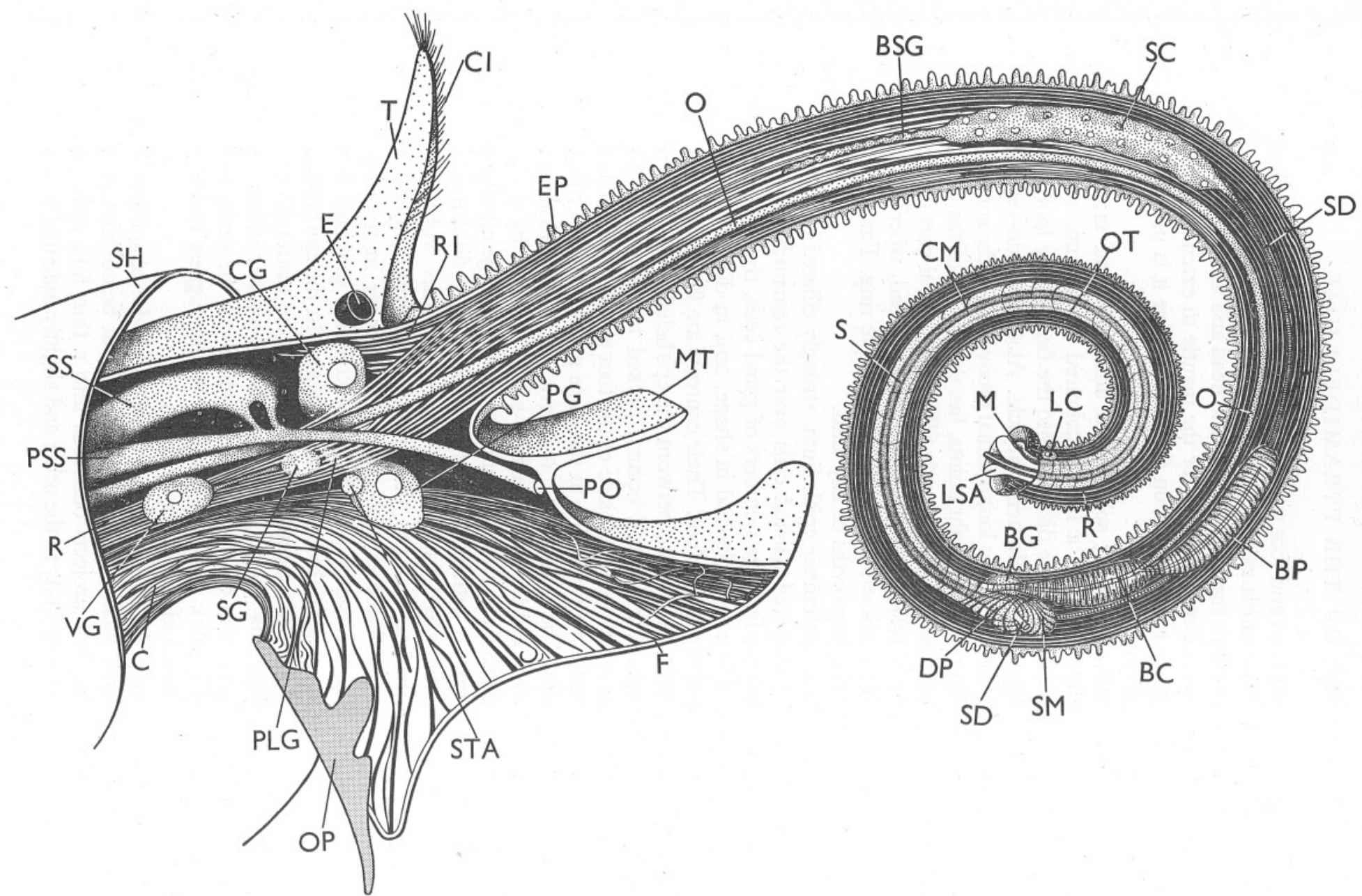

Fig. I. Odostomia unidentata. Sagittal half of the anterior end of a specimen protruding head and foot from the shell, and with the proboscis everted. The position of this is diagrammatic. The haemocoel is black, $\times$ c. 96. BC, buccal cavity; BG, buccal ganglion; BP, buccal pump; BSG, bladder of salivary gland; C, columellar muscle; CG, cerebral ganglion; CI, sensory cirri; CM, circular muscles; DP, dorsal pouch of buccal cavity; E, eye; EP, epithelial papilla; F, foot; LC, labial commissure; LSA, lip of stylet aperture; M, mouth; MT, mentum; O, oesophagus; OP, operculum; OT, oral tube; PG, pedal ganglion; PLG, pleural ganglion; PO, opening of penial sheath; PSS, penial sheath; R, retractor muscle of introvert; RI, protractor muscles of introvert; S, stylet; SC, cell of salivary gland; SD, salivary duct; SG, suboesophageal ganglion; SH, shell: SM, muscles moving stylet; SS, sperm sac; STA, statocyst; T, tentacle; VG, visceral ganglion. 
mid-line: this is the mentum (Fig. I, MT), a structure also to be found in the family Eulimidae (Kœhler \& Vaney, I908). At first sight it looks as if it were a snout, with the mouth at its tip, and the habit which Odostomia has of carrying it in front of the tip of the sole of the foot, in contact with the substratum, lends support to that view. Nevertheless, this structure is pedal, carries no openings at its apex and has no special histological characteristics, resembling in all respects other unspecialized parts of the foot. Ventral to this mentum, slightly to the right of the mid-line, is an opening (Fig. I, PO), that of the penial sheath.

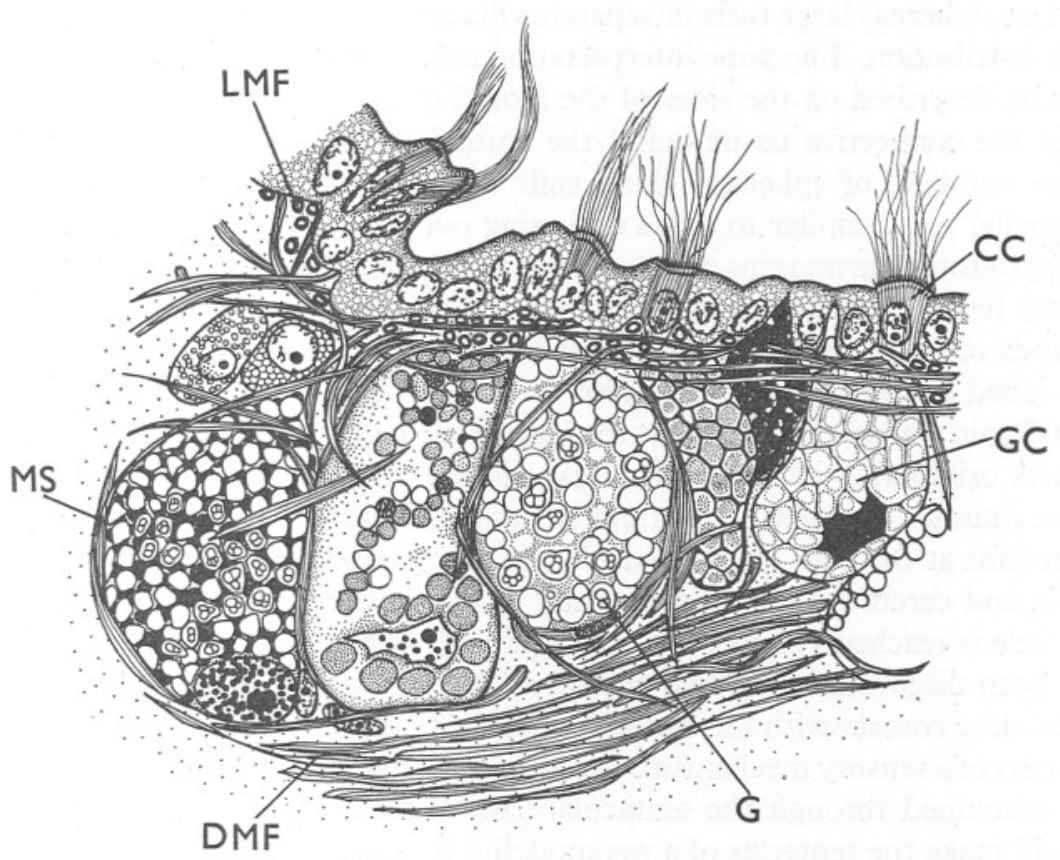

Fig. 2. Odostomia unidentata. Transverse section through lateral glandular streak. $\times 600 . \mathrm{CC}$, ciliated cell; DMF, dorsoventral muscles of foot; G, granulation; GC, gland cell; LMF, longitudinal muscles of foot; MS, muscles discharging secretion.

The head carries a pair of tentacles (T), a pair of eyes (E) and a pair of apertures - and there is something unusual about each of these structures. The tentacles are shaped like the ears of a donkey or rabbit, with a concave outer surface and, like the ears of these animals, they may be moved so that the concavity may face in a variety of directions. The cavity is lined by an epithelium, reminiscent of that covering the lateral parts of the foot: the cells are mainly covered with short, strong cilia which create a current of water that swirls into the concavity of the tentacle from the outer side and passes towards the mid-line as noted by Alder (Jeffreys, I867). When Odostomia is examined alive and feeding these tentacles are seen to project forwards from the head, 
diverging slightly, with the concavities facing forwards, downwards and slightly outwards. The movement of particles in the water shows that the cilia on the grooves draw a strong current in from over a considerable volume of water. Examination of living molluscs will also show the presence of long spike-like cilia projecting motionless from the surface and edges of the groove, most abundantly near the summit of the tentacle, which often appears fringed as a result. These, too, were noted by Alder. They seem to be sensory in nature and are probably compound structures, made by the functional fusion of many cilia, since in sections of fixed material no comparable cilia may be seen in these regions, whereas large tufts of separate cilia are to be found with similar length and distribution. The same interpretation may probably be applied to the tufts of cilia described on the sides of the foot (Fig. 2).

In the connective tissue below the epithelium of the tentacles there occur large numbers of spherical gland cells opening by ducts lying between the epithelial cells, similar to those occurring over the foot. They are sufficiently numerous for the margins of the spheres to be practically in contact. The centre of the tentacle is filled with a padding of connective tissue round the muscle strands responsible for the tentacular movements, but in addition to this there are lobed groups of cells that seem to be nervous and of the nature of small ganglionic masses. They arise at the base of the tentacle from a number of small nerves originating in the cerebral ganglia and they lie, mixed with the tentacular muscles and glands, in irregular masses under the epithelium, especially abundant at the base of the tentacles, in the proximity of the eyes and of the optic and cerebral ganglia, decreasing in size and number as the apex of the tentacle is reached. Their connexions (if any) with cells in the epithelium have not been discovered, but their certain relationship to the rich innervation, and their close contact with the epithelium of the tentacle suggest forcibly that they are part of a sensory mechanism. In conjunction with the stream of water which is maintained through the tentacular groove these cells and nervous masses would make the tentacles of a pyramidellid important organs for the sampling of the water in the neighbourhood of the animal.

The eyes of Odostomia and other pyramidellids lie close together under the skin of the head on the median side of the tentacles, instead of on stalks at the outer side as is usual in prosobranchs.

On the under side of the head lies the inconspicuous mouth. The opening of the penial sheath (Fig. I, Po) is present in every individual, as all these pyramidellids are hermaphrodite. From it a ciliated tract runs backwards along the right side of the head, ventral to the base of the tentacle, on to the floor of the mantle cavity to end at the single genital opening. Occasionally this tract is elevated above the general surface of the foot and head, over which it runs, so as to form a slight ridge. This is variable and is due to local muscular contractions.

Although the mantle cavity is narrow in a dorsoventral direction it is, never- 
theless, capacious, because of its width and the length to which it extends along the front of the visceral hump. To it discharge (i) the genital duct, in Odostomia about one-third of its total depth inwards from the mouth, lying at the bottom of a deep groove on the floor to the right near the mid-line; (ii) the kidney, by a minute pore projecting downwards from the roof, at the apex of a small papilla still deeper in the cavity; and (iii) the anus, a very small opening at the innermost end of the mantle cavity, on the floor, at the extreme left side (Fig. II, A).

The inner half of the mantle, which forms the roof of the inner part of the mantle cavity, is more or less equally occupied by two structures-the kidney, which, as in the small gastropods described by Fretter (I948), lies entirely in this position and not in the visceral mass at all, and which is placed immediately anterior and dorsal to the anus, lying on the left side; and, secondly, a vast glandular field, which extends on the right side to the innermost end of the mantle cavity. A narrow line of epithelium without glandular cells runs between the left edge of this area and the kidney, and a similar strip occupies the extreme right hand of the mantle cavity, so that the glandular region is clearly separated from neighbouring structures. Along its right-hand edge there runs a narrow strip-only about a dozen cells in breadth-of strongly ciliated epithelium, and this runs forward from the anterior end of the main glandular region to the mouth of the mantle cavity, which it reaches dorsal to and to the right of the head.

The inner half of the floor of the mantle cavity is less complex in its arrangement than the roof. The anus and genital opening lie on it and from the lips of the anus a glandular streak stretches at first across the mantle cavity from left to right and then forwards along the floor, passing to the right of the genital opening, and keeping more or less directly under the glandular area which lies on the roof of the mantle cavity, but clearly separated from it by the nonglandular strip of cells along the extreme right-hand margin of the mantle cavity. As in the dorsal area a strip of ciliated cells runs along the right-hand edge of the ventral glandular region, the two lying more or less one above the other, and this ciliated strip, too, continues to the mouth of the mantle cavity. Occasionally the two strips appear to be connected one to the other at the innermost end of the mantle cavity, but in other individuals they are clearly separate. The general arrangement is similar to what was described by Fretter (I948) in Omalogyra and Rissoella.

The outer half of the mantle is simpler than the inner and contains no special organ apart from the extensions of the ciliated strips already referred to. At no other place is the epithelium which covers it ciliated, and except at the mantle edge there are no gland cells; the epithelium is low, cubical or even squamous in character and permits ready exchange of respiratory gases between the water in the mantle cavity and the very rich bed of blood vessels which the mantle itself contains. This region would also appear to be a site of excretion, as numbers of amoeboid cells, the cytoplasm of which is loaded with spherules, 
may be seen in the blood spaces and in the act of passing out into the mantle cavity. These seem to be a source of great attraction to ciliates which regularly occur in large numbers in the mantle cavity of Odostomia, since wherever one of these cells is found in a pallial blood space or making its way through the epithelium of the mantle, there will always be found at least one ciliate hovering directly over it, presumably for the sake of ingesting the material which the cells are about to empty into the mantle cavity.

At the mantle edge a greater degree of histological differentiation has occurred: the cells of the epithelium are columnar and there are considerable numbers of gland cells lying in the pallial thickness. Some of these are simple mucous cells, but there are others the nature of the secretion of which is unknown. The greatest degree of histological complexity, however, occurs in the two glandular areas, dorsal and ventral. The former is composed of two types of gland cell: one is a mucous cell $(60 \mu)$, tall and wedge-shaped; whilst the second secretes spherules of a material which stains very darkly with iron haematoxylin when the secretion is being elaborated, but much less intensely at the time of liberation. These cells are of the same height as the mucous cells but are columnar in shape. In some parts of the field the two types occur in equal abundance and more or less alternately, but there are other regions, where mucous cells are most abundant, or even the sole type found; whereas along the edge of the glandular area that abuts upon the kidney mucous cells are practically never to be seen and the cells are all of the other type. This is also the kind of gland cell which predominates in the ventral fold, though here, too, mucous cells are mingled with them and, in the neighbourhood of the lateral tract, are more frequent. In the neighbourhood of the genital opening there occurs a grouping of a third variety, the cytoplasm of which is crammed with vacuoles, each filled with a mass of brown-coloured material. These are packed so tightly together that they are compressed into irregular, polygonal shapes staining erratically with iron haematoxylin. Whether they are ever shed, or whether they accumulate in the cells is not known, but they make a conspicuous linear mark, usually brown-orange or pink in colour, on the body of the mollusc-the anal gland of Lebour (1932), or larval kidney of Rasmussen (I944) - which is often visible by transparency through the shell, as in Rissoella Fretter (1948).

\section{The Alimentary Canal}

The aperture which lies on the under side of the head is not the true mouth, but merely the opening of an introvert at the base of which the true mouth is placed, so that the animal is provided with a proboscis of the acrembolic type. When retracted, the introvert is flung into an S-shaped loop, the anterior end passing through the nerve ring, and the bulk of the loop coiled posteriorly in the haemocoel. At its innermost end lies the mouth, which is placed in all pyramidellids on a circular sucker. The sucker is shaped rather like a candle- 


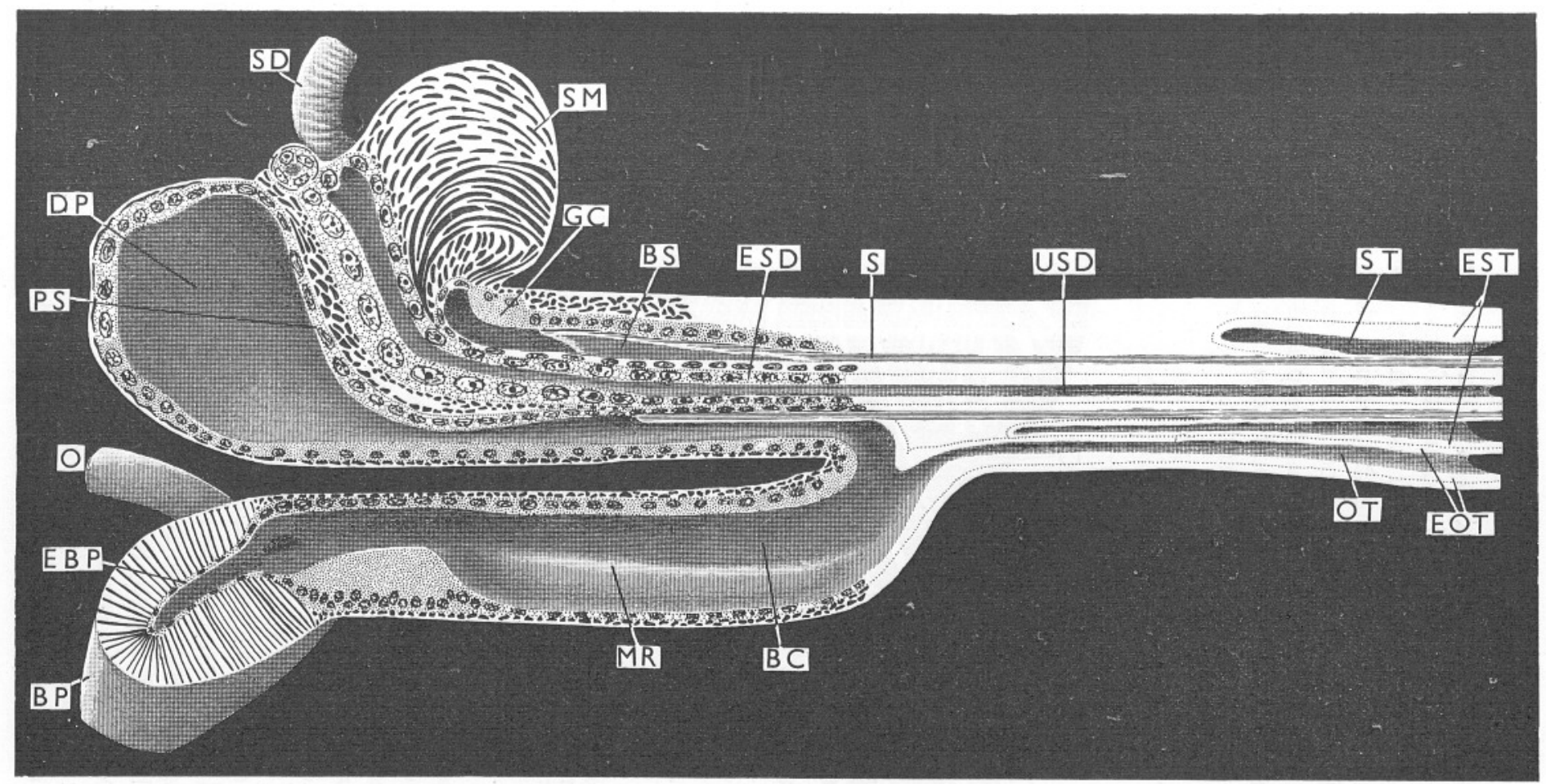

Fig. 3. Odostomia. Stereogram of a sagittal half of the base of the stylet and associated structures. $\times 600$. BS, base of stylet; EBP, epithelium of buccal pump; EOT, epithelium of oral tube; ESD, epithelium of salivary duct; EST, epithelium of stylet tube; GC, gland cell; MR, mucous ridge; PS, projection containing salivary ducts; ST, stylet tube; USD, united salivary ducts. Other letters as in Fig. I. 
stick, with an elevated central region as well as raised edges. In Odostomia spp. the mouth (Figs. I and 4, M) lies about half way between the centre and the edge of the sucker on the ventral side and is a narrow slit-like opening crescentic in shape. In addition to this opening there is a second lying in the centre of the sucker, with raised lips, and corresponding to the part of the candlestick into which the candle would be placed: this (Fig. 4, SA), as will be shown later, is merely a separated portion of the mouth, through which the animal can thrust a sharp spike-like stylet.

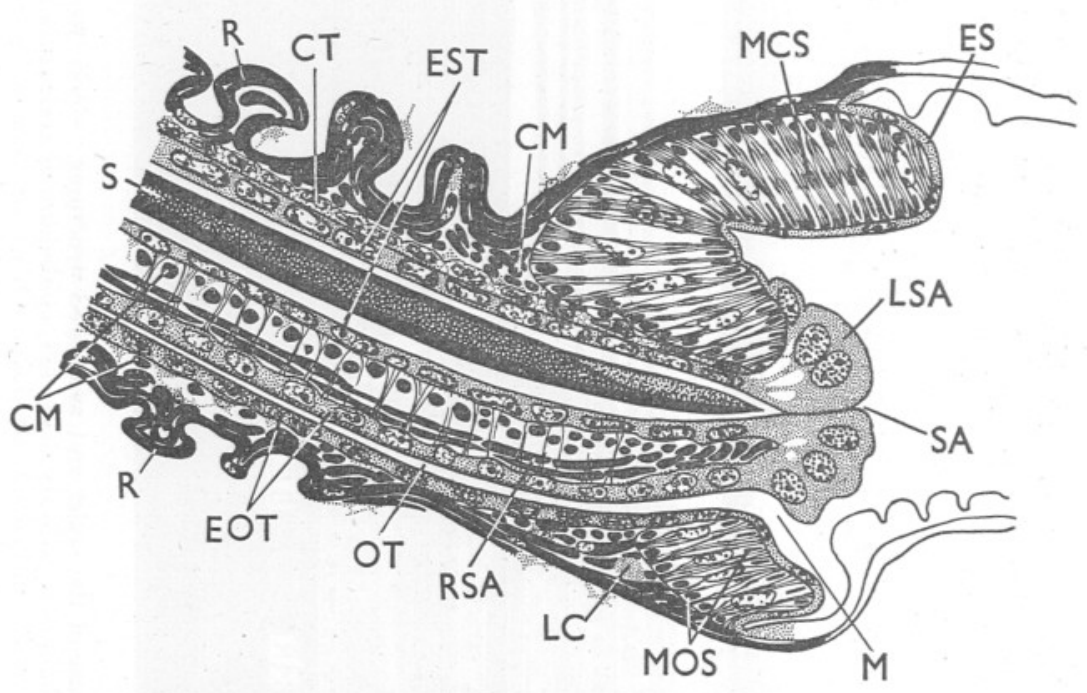

Fig. 4. Odostomia plicata. Longitudinal section through the mouth and initial part of the alimentary canal. $\times 600$. CT, connective tissue; EOT, epithelium of oral tube; ES, epithelium over sucker; EST, epithelium of stylet tube; MCS, muscles arching sucker; MOS, muscles flattening sucker; RSA, retractor muscle of lips of stylet aperture; SA, stylet aperture. Other letters as in Fig. I.

From the sucker there extends inwards an elongated initial section of the alimentary canal which will be shown later to be the oral tube. The main channel in this is the space (Figs. I, 3 and 4, OT), exceptionally narrow in a dorsoventral direction, which runs backwards from the mouth. Near its inner end the oral tube gives off a large, dorsally placed, blind pouch (Figs. I and 3, DP), which is part of the buccal cavity, and then its main channel turns towards the remainder of the buccal cavity and the oesophagus (Figs. I and 3, o). From its mid-dorsal point there projects into the pouch a long finger-like process (Fig. 3, PS), along the centre of which runs a single duct (Fig. 3, USD) formed by the fusion of the two ducts (SD) from the pair of salivary glands. The wall of the pouch into which this structure projects is, at the innermost end, a naked epithelium of rather flattened cells which is reflected on to the surface of the projection carrying the ducts of the salivary glands. Over a considerable area 
of the ventral wall of the pouch and, to a lesser extent dorsally, the cells are frequently mucus-secreting, whilst in the neighbourhood of the connexion to the rest of the buccal cavity, the epithelium is cuticularized, this production

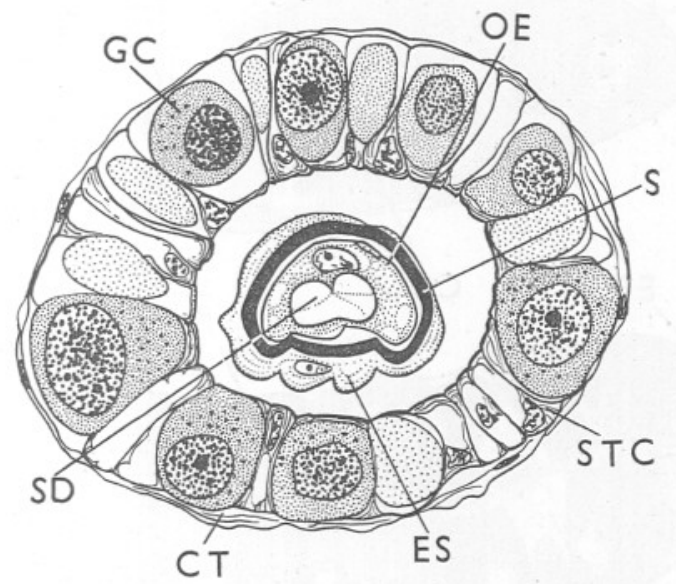

Fig. 5. Turbonilla jeffreysii. Transverse section through the stylet and oral tube. $\times 600$. $\mathrm{CT}$, connective tissue; ES, epithelium around stylet; GC, gland cell; OE, outer epithelium; S, stylet; SD, salivary duct; STC, supporting cell.

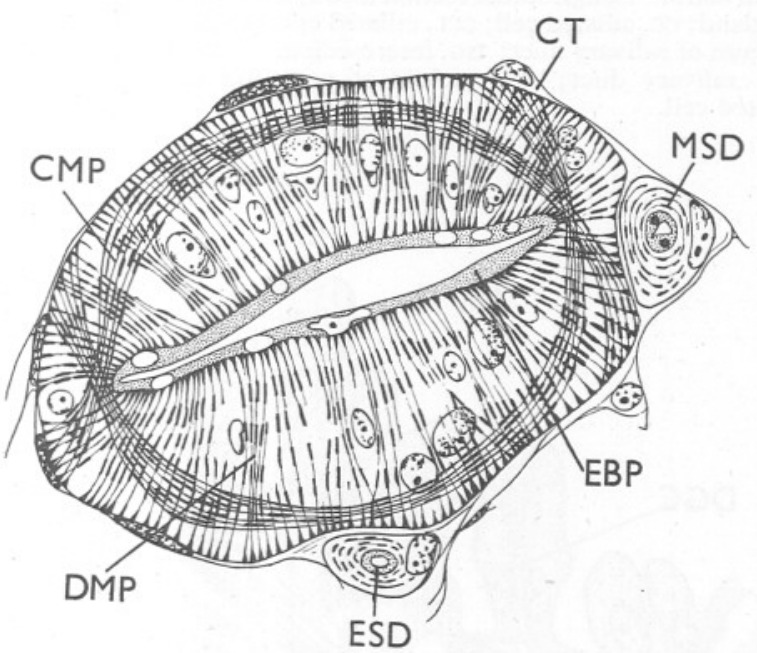

Fig. 6. Odostomia lukisii. Transverse section through the buccal pump and salivary ducts. $\times 600$. CMP, constrictor muscles of buccal pump; CT, connective tissue; DMP, dilator muscles of buccal pump; EBP, epithelium of buccal pump; ESD, epithelium of salivary duct; MSD, circular muscles of salivary duct.

of cuticle spreading along the dorsal wall of the pouch to the region of the narrow belt of mucous cells near the origin of the salivary process, but affecting the lateral walls to a lesser extent. The cuticle remains attached to the underlying epithelium dorsally and dorsolaterally, where the histological picture 


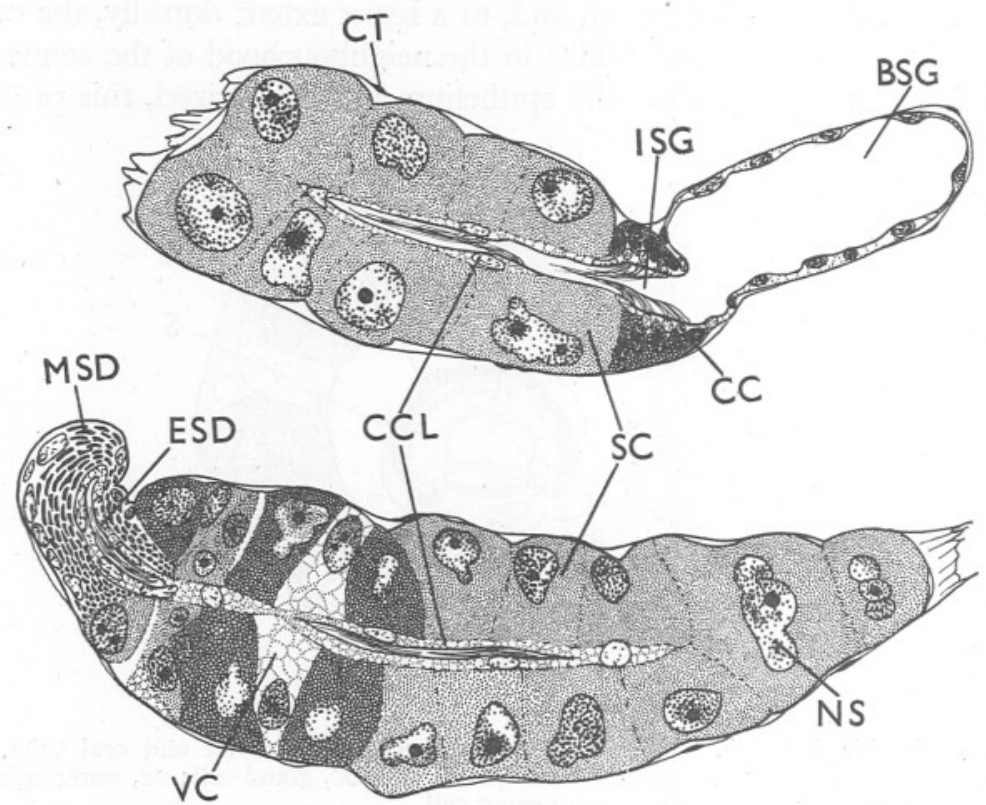

Fig. 7. Odostomia lukisii. Longitudinal section through the salivary gland. $\times 600$. BSG, bladder of salivary gland; CC, ciliated cell; CCL, ciliated epithelium of lumen; CT, connective tissue; ESD, epithelium of salivary duct; ISG, intermediate section of salivary gland; MSD, circular muscles of salivary duct; NS, nucleus of secreting cell; SC, cell of salivary gland; vC, vacuolated cell.

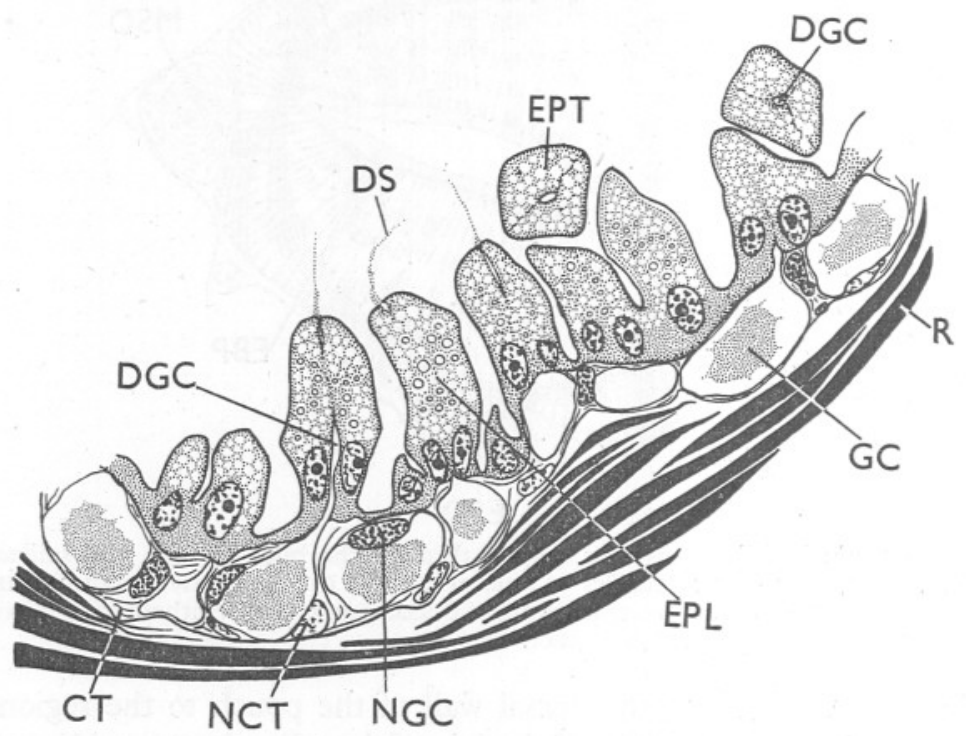

Fig. 8. Odostomia unidentata. Longitudinal section through a portion of the wall of the introvert. $\times 600$. CT, connective tissue; DGC, duct of gland cell; DS, secretion discharged to lumen; EPL, epithelial papilla in longitudinal section; EPT, epithelial papilla in transverse section; GC, gland cell; NCT, nucleus of connective tissue cell; NGC, nucleus of gland cell; $\mathrm{R}$, retractor muscles of introvert. 
shows obviously that it is being secreted, but more ventrally it grows freely into the cavity of the pouch, losing contact with the epithelium, and embracing, as it does so, the long projection in which the salivary ducts are running. The two edges of the cuticle actually grow around this until they meet midventrally in the cavity of the pouch near its mouth. In this way the common salivary duct, lying in the long process which grows out from the innermost part of the wall of the pouch, comes to be enclosed in a tubular cuticular sheath which is being continually added to at its base dorsally and dorsolaterally. On reaching the anterior end of the pouch, in Odostomia, this tubular cuticular structure plunges into the dorsal wall and runs for a short distance through the muscles and connective tissue of that wall. Soon, however, it emerges into a second space and runs along this to the sucker, where its anterior tip has already been described as projecting from the more dorsal of the two apertures which are placed thereon. At the base of this outer cavity the epithelium which lines it is reflected over the surface of the stylet, but this layer of cells is soon lost, and the stylet then lies naked in the cavity.

The epithelium which lines the oral tube (Figs. 3 and 4, EOT) is not remarkable in most places: it is a low cubical, almost squamous, epithelium with gland cells restricted to the dorsal wall of the space in which the stylet lies. These are mainly mucous, though a few secreting chromophile granules also occur. Sometimes these cells and the connective tissue cells around them lie under the dorsal epithelium of this cavity in such a regular way as to suggest the presence of a second epithelium in that position (Fig. 4, CT). At the lips of the mouth, and at the opening dorsal to that, through which the stylet is projected, this epithelium turns outwards over the concavity of the sucker, where it forms a very low and featureless layer of cells (ES), continued at the margin into the epithelium that lines the introvert. Only around the edge of the stylet aperture in the centre of the sucker is there any change in the character of the cells: here they are greatly enlarged (LSA), with vacuoles at their base, and large nuclei placed centrally in a mass of dense cytoplasm, so as to form a thick and rather fleshy looking rim to the opening.

The cells which line the innermost part of the introvert are shown in Fig. 8. They are raised in groups at regular intervals to form papillae, so that when the proboscis is thrust out and the lining of the introvert becomes the outer epithelium of the proboscis, it has a furry appearance (Fig. I). Each papilla, in Odostomia, consists of three or four cells lying side by side; they are crushed together in the centre of the papilla where they abut against each other, but smoothly curved towards the exterior, so that each papilla rises from a narrow base, swells to a greater breadth and then tapers to a blunt apex. Up the centre of each papilla, through a long tube that seems to be formed along the line of meeting of the cells, runs a duct (Fig. 8, DGC) from a subepithelial gland placed in the connective tissue of the wall of the introvert (GC); and this opens by a minute apical opening to the lumen of the introvert when the 
proboscis is withdrawn, or directly to the exterior if the proboscis be extended. The glands are spherical in shape and their contents are finely granular, reminiscent of those that lie in the outer surface of the head and on the sides of the foot-and as the introvert has presumably arisen by the in-pulling of a greatly extended snout the glands are in fact probably the same: it is their special way of opening in relation to the other cells of the epithelium which is of interest. The cytoplasmic organization of these cells, too, is in some ways specialized: the nuclei are always large and placed basally side by side in the narrow neck of the papilla. The cytoplasm is dense and contains a number of small spherules lying in irregular vacuolations which do not stain differently from the other parts of the cytoplasm, but the most superficial layer is distinctly denser than any other part and after staining with mucicarmine it has frequently a pinkish tint. On some occasions, too, it has appeared as if the cortical region were striated. In the parts of the introvert lying nearer the external opening the characteristic arrangement of papillae is gradually replaced by an ordinary columnar epithelium, the height of which does indeed vary somewhat from spot to spot, but not in the regular way which has just been described. The cells are all of similar height, their cytoplasm not specially organized and the number of gland cells reduced and without any noteworthy relationship to the others.

Underneath the epithelium of the buccal region lies a complex array of muscle fibres, many of which are part of the mechanism for the retraction of the extended proboscis. The fibres which are responsible for the greater part of the retraction (Figs. I and 4, R) are set on the edge of the sucker, curve round its inner face and then travel as a muscular sleeve around the stylet and oral tubes towards the inner end of the latter. The fibres of the sleeve are not, however, all parallel to one another, but gradually converge to form a closely knit bundle of muscle, lying to the ventral side of the gut. This then runs up the visceral hump alongside the columellar muscle, and is inserted like that on the columella of the shell, high up the spiral of the visceral hump. When the proboscis is extended the retractor muscle is of course relaxed and stretched taut, running alongside the gut along the whole length of the proboscis, through the nerve ring and thence on to the columellar muscle; when it is contracted it is flung into a large S-bend, one of the angles of the $\mathrm{S}$ being in the neighbourhood of the buccal ganglia, the other, the more distal, near the origin of the stylet. The fibres during their course from the columellar muscle to the ganglia, and then on to the second bend, are straight when contracted; those from the second bend to the sucker, however, are flung into great loops when in the same state. Subsidiary bundles of muscles run from the wall of the introvert directly to the body wall (Fig. I, R I). All these bundles run through the nerve ring when the proboscis is retracted, and they will therefore help in its extension. This, however, is presumably brought about mainly by the pressure on the blood in the haemocoel exerted by the musculature of the body wall. 
In addition to the retractor muscles there are other, intrinsic, muscles of the gut wall which help in the movement of the stylet and presumably in the feeding movements as well. The latter are mainly due to circular fibres which constitute a muscular coat of considerable dimensions lying directly within the longitudinal sheet formed by the retractors. The thickness of the coat is less at the outer end, in the neighbourhood of the sucker, than at the inner end, near the dorsal pouch of the buccal cavity, where the fibres are elaborated into a muscular mass of great complexity around the base of the stylet and the point of entry of the salivary ducts. Here they are responsible for the movements of the stylet (Figs. I and 3, SM). Further bundles of circular muscle fibres lie around the oral tube (Figs. I and $4, \mathrm{CM}$ ) and are presumably involved in peristaltic movements affecting that region, whilst a bundle of longitudinal fibres which runs up to the lips of the stylet aperture (Fig. 4, RSA) would apparently pull these back, and help in this way to expose the tip of the stylet.

All the muscles so far described are unstriated.

The sucker, by which animals of this genus obtain a grip on the body of the creatures upon which they feed, is provided with musculature arranged in the same plan as in platyhelminths. There are three sets of intrinsic muscles involved. A series of cells runs through the depth of the sucker between its inner and outer surfaces (MCS), attached to the under side of the epithelial cells which cover the sucker in the latter position, and ending on a sheet of connective tissue in the former. When they contract, the degree of concavity of the sucker is increased and its grip augmented. Antagonizing these is a double set of circular muscles (MOS) which lie between the ends of the cells of the first set, one group just under the outer epithelium, the other just within the inner layer of connective tissue. All these muscle cells contain groups of fibrillae and these are all striated, though the striation appears to be less complex than in vertebrate muscle cells.

The main part of the buccal cavity continues behind the point at which the dorsal pouch (Figs. I and 3, DP) is given off. This section is histologically similar to that pouch, with part of the wall, dorsally, near the origin of the pouch, cuticularized, and the rest rich in mucous cells. These are especially abundant ventrally, where they form two longitudinal ridges, one on either side of the mid-ventral line. Anteriorly the space between these ridges is a narrow groove lined by cells which are not glandular, but at the innermost end of the cavity the ridges converge so as to obliterate the groove, though the type of cell which lies at this spot does not alter. A thin coat of circular muscle surrounds this.

The character of the gut changes abruptly at the hinder end of this section where an extremely muscular organ, the buccal pump (Figs. I and $3, \mathrm{BP}$ ), is developed. This is a short length of the gut divisible into two halves, with the oesophagus (Fig. I, O) coming out ventrally near the middle, its point of attachment coinciding with a constriction separating the two halves. The 
second half of the pump is therefore a caecum. Both parts, however, are identical in general plan (Fig. 6); they are flattened in a dorsoventral direction with a narrow central cavity. Their walls are very thick, by far the greatest part of this being due to the development of muscle fibres, and in general, they are very reminiscent of the structure of the sucker. The epithelium (EBP) which lines the pump is extremely low ( $2 \mu$ in height) and rests directly on the muscle of the wall. The bulk of this is formed of radial cells (DMP) fastened to the under side of the epithelium externally and to a sheet of connective tissue internally. Each cell, as in the sucker, has bundles of contractile fibrillae differentiated in its cytoplasm and these are all striated. Clearly, when these contract, they will give a strong and probably sudden pull on the epithelium, which will increase the dorsoventral diameter of the lumen of this part of the gut and so increase the volume. Antagonists (CMP) to this set of radial fibres are provided by transverse sheets of fibrillae, also striated, which run rather more than half way across each side of the cavity; their contraction will restore the cavity to its original volume.

Both these and the preceding section of the gut are closely linked with the salivary glands (Fig. I, SC, SD), of which one pair is present. They lie freely in the haemocoel, though they may be attached to the body wall at their tip by fine strands of connective tissue or muscle. Each gland is connected to the gut by a long duct (Fig. I, SD), and in the gland itself three distinct sections may be distinguished. The section lying next to the duct (Fig. 7) is composed of a series of large cells more or less quadrilateral in section. Their outer ends bulge slightly outwards against the layer of fine connective tissue (CT) that separates them from the haemocoel and it is noticeable, both in sections and in the intact gland, that the cells along one side alternate with those of the other. Almost all the cells have the same appearance-dense, even and darkly staining (iron haematoxylin) cytoplasm containing a large and irregularly lobed nucleus with a prominent nucleolus and many small granulations, the shape of the nucleus probably being an indication of intense metabolic activity (NS). In the few cells nearest to the ducts the cytoplasm is sometimes denser than in those farther away and the cells seem smaller and less well fitted together into an epithelium. An occasional cell (vc) will sometimes be distinct from all its neighbours and have a palely staining cytoplasm. Strictly speaking these are all subepithelial gland cells, because the lining of the central lumen is a layer of squamous epithelium bearing tufts of long cilia (CCL); these may be seen beating actively when a living gland is examined. The second section of the gland is brief and lies at the inner end of the secretory region: it is a short length where the same relationship of alternating ciliated and glandular cells occurs, but here the gland cells are small (ISG); they lie in the epithelium and stain even more intensely, whilst the ciliated cells (CC) are wedge-shaped with a long stalk connecting them to the basement membrane, and with their nuclei near the cilia. The lumen of the gland is broader and the cilia seem to beat with greater 
vigour-though that may be merely an illusion occasioned by the fact that they have more space in which to beat. The innermost part of the gland is a thinwalled bladder (Figs. I and 7, BSG), lined by a squamous epithelium without cilia and without any obvious glandular appearance. The ducts are lined by an extension of the epithelium which lines the gland, but the greater part of the thickness of their wall is due to a great development of muscle cells containing circularly running fibrillae underneath the epithelium (Figs. 6 and 7, MSD). Like the fibrillae of the sucker and the pump these are striated. The two ducts run to the wall of the distal half of the pump, course along the lateral walls of that until the neighbourhood of the buccal cavity is reached, when they pass dorsally to enter the prolongation (Fig. 3, PS) which has already been described. There they unite, lose their muscular coat, and the single duct runs down the centre of the stylet to discharge saliva at the tip. When the proboscis is retracted the ducts coil irregularly in the haemocoel: when that is everted they are straight.

There are several points in the appearance of the salivary glands that suggest that there is a holocrine secretion occurring there without a restitution phase. The appearance of the cells at the two ends of the secretory part is unlike, though all the cells in a given region resemble one another. The cells are invariably larger at the inner part of the proximal region and invariably.small and the epithelium less well compacted at the outer end of the same stretch, whilst if there were secretion going on from the entire gland, either in a rhythmic or arhythmic fashion, now and again a section would show cells of the latter variety in other parts of the gland. Although we have no direct evidence on this point the appearance of the gland would suggest that there is a continual (or rhythmic or post-prandial) production of new cells from the middle region of the gland, and that the cells mature their secretion as they move towards the ducts along the outermost section of the gland, discharging it, and being destroyed in the process, when they reach the outer end of this, at the beginning of the duct.

The oesophagus (Fig. I, o) originates from the inner end of the first half of the buccal pump (BP). It is a tube of capillary dimensions $(6-8 \mu)$ at its origin, but its diameter increases slowly and steadily as it runs up the visceral hump till it ends by opening into the stomach. It behaves like the ducts of the salivary glands, with which it is, in fact, closely associated: when the introvert is withdrawn into the body it coils in a close tangle with the salivary ducts; when the proboscis is thrust out it is stretched straight. The oesophageal walls are similar from one end to the other; the lining is a columnar epithelium, most of the cells having a very fibrillar cytoplasm. Occasional cells are probably glandular because they have numerous uniform, refringent spherules enclosed within them which are not dissolved in any fixative and are darkly staining. In Turbonilla jeffreysii, which feeds on coelenterates, a short terminal region of the oesophagus, of slightly larger diameter than the rest, has every cell filled 
with nematocysts. It would appear that a certain amount of phagocytosis of food particles goes on here, and it may also be true of Odostomia, although the fluid nature of the food does not allow it to be made readily visible.

The stomach into which the oesophagus leads barely merits the name, as it cannot be distinguished from the digestive gland, a condition reminiscent of Omalogyra (Fretter, 1948). Except for the immediate neighbourhood of the oesophageal opening the entire epithelium is occupied by digestive cells and these are invariably packed full of brown spherules, which are darkly staining. A few cells in the digestive epithelium are of a different type: their nuclei are large and are, in fact, the only nuclei easily visible in sections, for they differ from the digestive cell in that the spherules in the cytoplasm are dissolved in acid fixatives. The gland occupies the greater part of the visceral hump, lying on the outer, convex, side of the spiral.

The intestine arises close to the oesophageal aperture and runs almost directly to the upper end of the mantle cavity, passing close to the vas deferens as it does so. The epithelium is ciliated. The anus lies on a small papilla.

\section{The Vascular System}

The vascular system of Odostomia is built upon the usual gastropod plan, but is modified in certain respects which may be of functional significance.

The heart lies in a pericardial cavity placed within the visceral hump, at the attachment of the mantle skirt on the left side, immediately proximal to the kidney, which opens to it in the usual way. The single auricle lies anterior to the ventricle, from which only one aorta emerges, at the inner end of the pericardial cavity. This vessel climbs up the visceral hump, on the concave side of the spiral, resting on the surface of the gonad which, in turn, is enwrapped by the digestive gland, so that it is plain that it corresponds to the posterior aorta of other molluscs. Longitudinal muscle fibres lie in the aortic wall. Near the apex of the visceral hump the posterior aorta opens into a haemocoelic space interpenetrating the lobules of the digestive gland and gonad. This drains into a second vascular channel which passes down the visceral hump on the outer, convex side so that it is wrapped around (save where it is pressed against the mantle) by digestive gland. At the level of the heart this expands into a vast haemocoelic space in which the pericardial cavity itself and the bulk of the structures in connexion with the reproductive system are placed, and through which the intestine and the upper end of the oesophagus also pass. From this chamber two vessels run forwards. Of these one passes into the head and then forwards and ventrally into the foot and it would therefore seem to correspond to the anterior aorta of other molluscs, although its central connexions are different. As it runs forwards, it lies immediately under the floor of the mantle cavity, raising that up so that it projects into the mantle cavity as a long ridge. In this part of its course it lies alongside the genital duct; on reaching the head 
it dives deeply into the body, curving behind the nerve ring down the right side, so as to pass ventral to the pedal ganglia in the middle line of the anterior portion of the foot, and it ends here by opening into the main haemocoelic space of the body, occupying head and foot, in which are placed all the viscera of the animal except such as are situated in the visceral hump. The second vessel which leaves the upper haemocoelic space (the afferent pallial) runs into the roof of the mantle cavity and discharges blood into the numerous sinuses with which that part of the body is filled. The main pedal and cephalic haemocoelic cavities also drain into this region. Blood collects from the mantle into another vessel (the efferent pallial) which finally enters the auricle at the upper end of the mantle cavity. Before reaching that organ, however, the blood has to pass through a capillary bed on the wall of the kidney: in sections it may be seen that the outer wall of the kidney, especially where it is contiguous with the lining of the mantle cavity, is corrugated, and that the blood from the pallial sinuses must trickle along the tiny channels made by these corrugations in order to reach the main efferent vessel by which the auricle is gained.

The main course of the circulation is obvious. Blood is pumped by the heart up the posterior aorta to the organs placed in the visceral hump, and in minute, shelled gastropods like Odostomia it is clear that these are the only organs which will require a direct blood supply of this nature, since they are the only parts of the body continuously enclosed within a shell and so liable to suffer from oxygen lack. Under normal circumstances, with the body of the animal not shut inside the shell, head, foot and mantle will all act as respiratory surfaces, and it is unlikely that the blood will ever be significantly short of oxygen. Movements of the blood in the principal haemocoels are more likely to be produced by the movements of the head and foot and proboscis than by the beating of the heart, and, in particular, every time that the proboscis is everted-a process largely brought about by the hydraulic action of the blood in the cephalic haemocoel-and again when it is withdrawn, there must be produced powerful currents and disturbances in the vascular system. The special arrangement of the anterior aorta seems likely to be connected with this: its origin from a blood space instead of directly from the ventricle will ensure that this vessel can pour blood into the haemocoelic spaces of the head and foot as the proboscis is everted and, on the other hand, when the reverse process is taking place, the upper haemocoel will provide a storage place for the blood and will prevent damage to the heart that might have been difficult to avoid had that structure been connected directly to the haemocoel by the aorta.

Two other points in the vascular system deserve comment. One of these is the frequency of blood cells: these may be found in many of the vessels, but are most common in the spaces in the roof of the mantle cavity, in the anterior aorta and caught against strands of muscle in the chambers of the heart (Fig. 9). They are spherical in shape, with a round nucleus placed to one pole; the cytoplasm is not prominent apart from irregularly placed, scattered, or clumped 
spherules which are invariably present, staining darkly with iron haematoxylin. These granulations are presumably excretory in nature, and one of the main activities of these cells would seem to be the transport of such particles to places where they may be cast out of the mollusc. This probably explains their abundance in the sinuses of the pallial region as it is mainly there, as recorded above (p. 500), that the cells have been seen in the process of discharging their contents to the mantle cavity. It is not certain whether they do not pass out themselves at the same time.

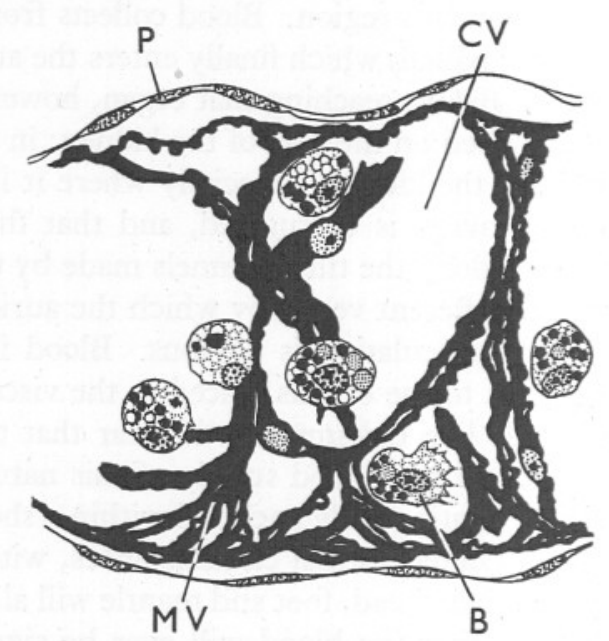

Fig. 9. Odostomia unidentata. Section through ventricle of heart to show blood cells. $\times 600$. $\mathrm{B}$, blood cell; $\mathrm{CV}$, cavity of ventricle; MV, muscles of ventricle; $\mathrm{P}$, pericardium.

The second feature connected with the vascular system of Odostomia which should be noted is a differentiation of the wall of the anterior aorta where it runs forwards towards the head, alongside the terminal part of the genital duct. Here the cells which line the aortic wall abutting against the genital tract are specialized to form a thick pad of tissue. They are quadrilateral when seen in section, each with a large, darkly staining and granular nucleus; the cytoplasm is also granular. The nature of this group of cells is unknown.

\section{The Nervous System}

The ganglia of the nervous system of Odostomia are mainly concentrated into a ring which envelopes the proboscis, and also, quite unexpectedly, the penial sheath, and in which nine ganglia may be distinguished. In addition to the constituents of this ring two other paired ganglia may be observed in relation to the introvert, and a single unpaired one lies in the mantle on the animal's left side. A diagram of the nervous system is given in Fig. IO. Dorsal to the introvert lie the two cerebral ganglia (Figs. I and IO, CG): they are large, oval 
in cross-section and the commissure between them so short that they are practically joined across the middle line. Anteriorly and ventrally they are drawn out into lobes (Fig. IO, LO, SL) which project considerable distances towards the eyes, the tentacles, and, to a lesser degree, the sides of the body between head and mentum. These merge into the ganglionic masses already described in these situations, and the main nerves for these regions arise out of these swellings.

Ventrally the cerebral ganglia are connected to the pedal ganglia (Figs. I and IO, PG), which are about equal to them in size, and, like them, are closely approximated, so that the commissure is hardly a separate structure. The cerebro-pedal connective is likewise rather short. On the postero-dorsal faces of the pedal ganglia lie the statocysts (Fig. I, STA) in each of which is placed, as already noticed by Pelseneer (I899), a single calcareous statolith. At least four nerves leave each pedal ganglion and pass into the musculature of the foot. From each cerebral ganglion there also leaves a second connective, arising so close to the point of origin of the cerebro-pedal connective that it requires close observation to be sure that there are indeed two. A strip of muscle running from body wall to introvert, however, is regularly found separating the two structures, so that there is no real doubt that these are two independent nerves. The posterior of the two connectives runs to a small ganglion lying between the cerebral above and the pedal below, to which it is also linked by a further connective,

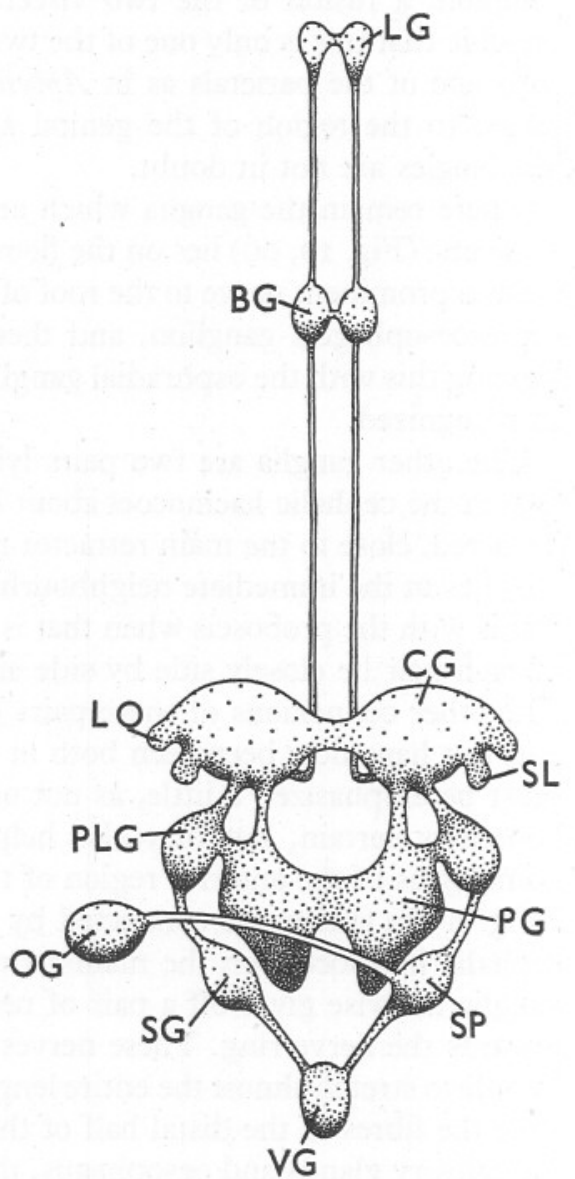

Fig. Io. Odostomia. Diagram of nervous system in dorsal view; the proboscis is supposed to be everted. LG, labial ganglion; OG, osphradial ganglion; LO, optic lobe; SL, sensory lobe; SP, supraoesophageal ganglion. Other letters as in Fig. I. and placed slightly posterior to both (Fig. IO, PLG). This is clearly the pleural ganglion on each side.

From the pleural ganglia there may be traced a visceral loop lying ventral to the introvert and not exhibiting any torsion. It is much abbreviated and does not extend far behind the rest of the nerve ring. On this loop three ganglia may 
be distinguished, and the most likely interpretation of these is that the one attached to the right pleural (Fig. IO, SP), is the supra-oesophageal ganglion, the one attached to the left pleural (Figs. I and IO, SG) is the suboesophageal ganglion, whilst the remaining ganglion would then represent the abdominal ganglion, a fusion of the two visceral ganglia (VG). It is, however, always possible that this is only one of the two visceral ganglia, the other having fused with one of the parietals as in Aplysia. Nerves arise from these that can be traced to the region of the genital aperture, kidney and heart so that their homologies are not in doubt.

There remain the ganglia which are not closely tied to the nerve ring. Of these one (Fig. IO, OG) lies on the floor of the mantle cavity on the left side and sends a prominent nerve to the roof of the mantle cavity. It is connected to the supra-oesophageal ganglion, and there is therefore little difficulty in homologizing this with the osphradial ganglion, although no specific osphradium can be recognized.

The other ganglia are two pairs lying in relation to the introvert, one pair (BG) in the cephalic haemocoel about half way along the introvert when that is retracted, close to the main retractor muscle of the proboscis. The second pair (LG) lies in the immediate neighbourhood of the sucker. Both pairs move outwards with the proboscis when that is extended (Fig. I, BG, LC). The members of each pair lie closely side by side and are connected by short commissures. The other connexions of these pairs of ganglia have proved difficult to make out, but have now been seen both in dissections and in sections, a fact which must be emphasized a little, as not only do their connexions make their own homology certain, but they also help in establishing beyond any doubt the homologies of the anterior region of the alimentary canal. The pair of ganglia lying in the sucker are connected by a pair of nerves to the pair lying in the cephalic haemocoel on the main retractor muscle of the sucker. This pair of ganglia likewise gives off a pair of nerves which runs through the haemocoel towards the nerve ring. These nerves are particularly long because they must be able to stretch almost the entire length of the proboscis when that is extended. Like the fibres of the distal half of the retractor muscle, and like the ducts of the salivary glands and oesophagus, they are, for this reason, sinuously looped when the proboscis is retracted and straightened on the extension of that part of the body. On reaching the nerve ring the nerves pass dorsally and approach the cerebral ganglia, each nerve entering into a little lobe placed in a posteroventral position on the cerebral ganglion. When one compares the plan of this . part of the nervous system in a pyramidellid with the general plan of the gastropod nervous system, it is plain that only one interpretation of the homologies of these ganglia is possible: the pair which is connected to the cerebral ganglia must be the buccal ganglia, whilst those that lie in the sucker, that is in the lips of the mouth, must be the labial ganglia. The whole stomatogastric system must lie ventral to the main channel of the gut, though the 
buccal commissure would be dorsal to a radular sac, from which it must be concluded that the side of the mouth on which the ganglia are placed is ventral.

\section{REPRODUCTION}

The pyramidellids are simultaneous hermaphrodites: ripe sperm and ova lie side by side in the same tubules of the gonad. The simpler requirements of the male reproductive system enable young individuals to function as males until the ova and the relatively enormous glands associated with egg laying are mature. Both types of gamete use the same ducts and are liberated into the mantle cavity through the same genital aperture. The path of the spermatozoa is, however, extended from here by the ciliated seminal tract which leads along the floor of the mantle cavity and around the base of the right tentacle to the penis.

Fig. II shows the disposition of the reproductive organs of a mature individual. From the gonad (H), on the columellar side of the visceral mass, a narrow though very distensible genital duct (GD), lined by a columnar ciliated epithelium, takes a somewhat sinuous course through the haemocoel towards the posterior end of the mantle cavity. Immediately after leaving the gonad it is distended with sperm (v), acting in this region as a vesicula seminalis; sperm are stored here even during a period of spawning, when the ova make their way, one by one, through the mass of ripe spermatozoa. From the vesicula seminalis the duct loops under the intestine (I) and describes a $U$-shaped bend around the posterior aorta before passing forwards to open into the pallial hermaphrodite duct (GO). Along the final part of its course it receives the openings of three glands which are concerned with the production of the egg masses. Two of these, the albumen gland ( $\mathrm{AG}, \mathrm{DA})$ and the mucous gland (MGU, DU), open close to one another; the third opens near the entrance to the pallial duct and is a second mucous gland attaining a greater size than the first (MGL, OL). The white, flocculent lobes of the albumen gland tend to embrace those of the upper mucous gland. In both, as elsewhere in the genital system, the secreting cells in the epithelium alternate with small ciliated cells wedged between their distal ends (GC, CC). The secretion within the cells of the albumen gland is in the form of spherules which stain lightly with Heidenhain's haematoxylin and are embedded in a more deeply staining cytoplasm; in sections the secretion can usually be found in the form of a plug blocking the narrow duct which leads towards the genital aperture. The two mucous glands can not only be distinguished by a difference in size, but also by a difference in the staining properties of the component cells: those of the lower one respond to stains which are specific for mucus more readily than those of the upper. This distal gland is the last to appear in the development of the female system, but its growth is rapid and its lobes soon come to envelope the proximal end of the pallial duct, often extending halfway down its length. 
The pallial genital duct is divisible into two regions: a proximal glandular part (GO) occupying about half of the length and expanding posteriorly as a commodious pouch, and a distal ciliated, conducting region which is more muscular. Running along the median wall of the former, and as a less conspicuous tract distally, is a ciliated gutter which is confluent with the narrow

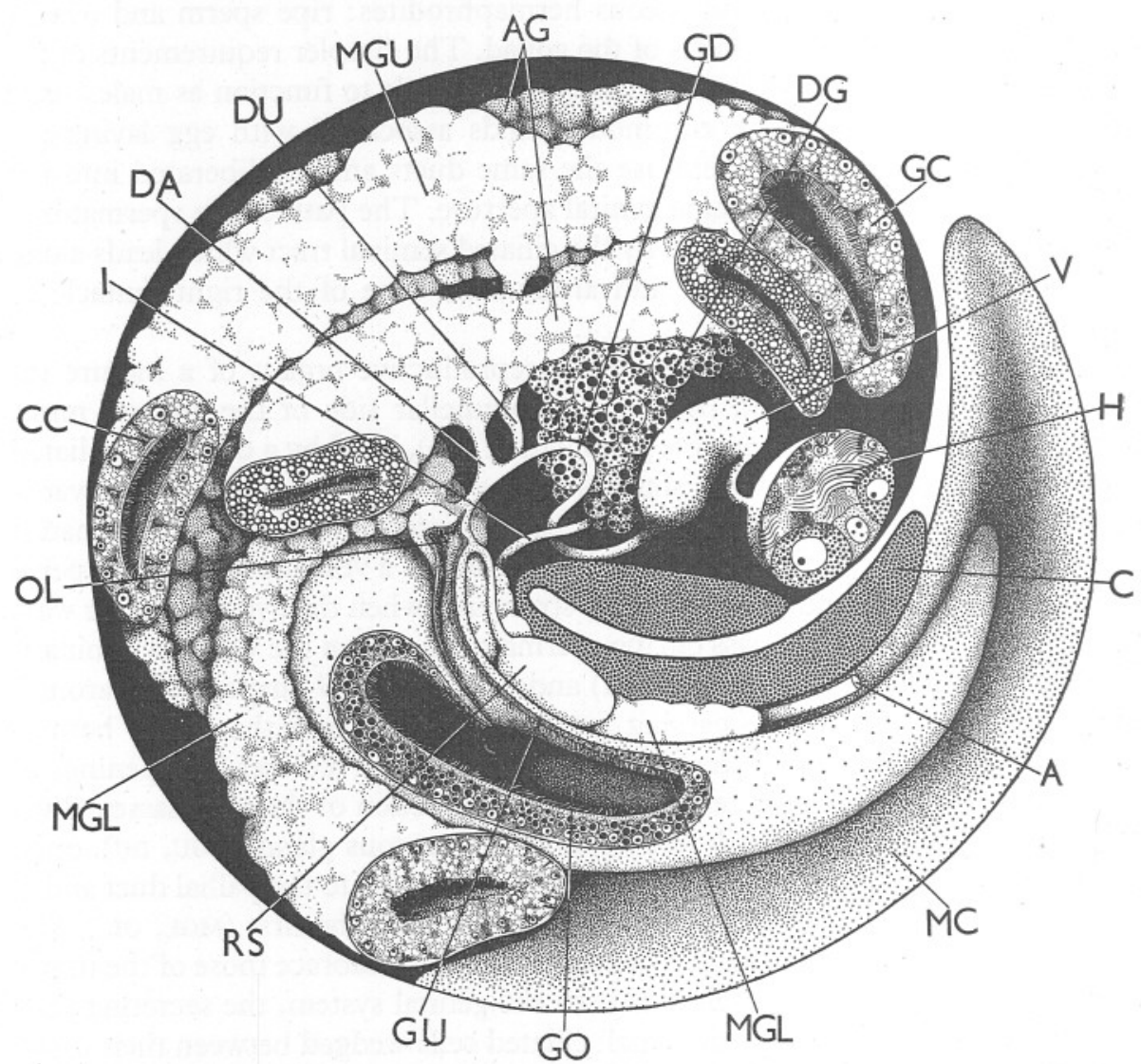

Fig. Ir. Odostomia lukisii. Stereogram to show the disposition of the reproductive organs. The visceral hump has been cut across at the level of the reproductive ducts and the cut surface is viewed from above; the haemocoel is black. × 104. A, anus; AG, albumen gland; C, columellar muscle; CC, ciliated cell; DA, duct of albumen gland; DG, digestive gland; DU, duct of upper mucous gland; GC, gland cell; GD, gonadial duct; GO, glandular part of pallial hermaphrodite duct; GU, gutter along GO; H, hermaphrodite gland; I, intestine; MC, mantle cavity; MGL, lower mucous gland; MGU, upper mucous gland; OL, opening of lower mucous gland into pallial hermaphrodite duct; RS, receptaculum seminis; v, seminal vesicle.

hermaphrodite duct (GU). Initially this channel communicates with a globular receptaculum seminis (RS) in which unorientated sperm are always to be found. An excess of spermatozoa may surround the entrance to the duct of the receptaculum and extend in all directions from there. The gland cells of the 
pallial duct are the first to differentiate and to become functional: during early sexual activity, when only the male system is mature, the cells are distended with large secretory spherules of a protein nature. Later, during a period of egg laying, the appearance of the cells suggests that they are inertreduced in size, with less abundant and smaller spherules which stain not uniformly, but in varying degrees of intensity, with both iron haematoxylin and azan. This gland is, therefore, assumed to be a prostate, and it is uncertain whether it has any function during the female phase.

The outstanding characteristic of the reproductive system of the pyramidellids is the position of the penis: in no other family does any structure except the digestive tube and its intrinsic glands and muscles pass through the nerve ring. In the pyramidellids, however, this position is also occupied by the penis (Fig. I). The penis is invaginable and completely concealed except during copulation, when, as a long whip-like structure, turgid with blood and tapering to a fine point, it is passed into the mantle cavity and through the genital aperture of the partner. The penis retracts into a tubular sheath (PSS), within which it lies freely, like a partly invaginated finger of a glove, with its tip at some distance from the external aperture (PO). The sheath lies in the haemocoel dorsal to the gut and may be flung into one or two broad loops when the animal is withdrawn into its shell. The walls of the penis and its sheath are continuous and retraction is brought about by their intrinsic muscles (Fig. I2, CM, LM) and the consequent expulsion of blood into the general haemocoel. These muscles resemble those of the buccal pump in that the fibrillae are striated. Opening into the dorsal wall of the penial sheath in front of the tip of the retracted penis is the short, wide duct of a large, muscular sac which lies immediately within the body wall (Fig. I, ss). The sac and its duct are ciliated, the cilia exceeding five times the height of the cells in length. An epithelium with long, closely set cilia also lines the anterior part of the sheath to the external opening (PO). Elsewhere the epithelium of the sheath, and also that of the penis, are cuticularized. A second duct, the vas deferens, arises from the muscular sac closely behind the first and runs in the thickness of the dorsal wall of the sheath (Fig. I2, VD) towards the base of the penis into which it passes (VDI), to open at the tip. It is not ciliated, but its walls are muscular. The path of the spermatozoa from the common genital aperture can thus be followed along the seminal groove through the anterior ciliated part of the penial sheath into the sperm sac and thence to the tip of the penis along the vas deferens.

During copulation the individual which acts as male creeps on to the dorsal surface of the shell of its partner, everts the penis and bends it ventrally to reach the mantle cavity of the female. Animals which have been separated during copulation, fixed and sectioned, show, at least as far as that acting as female is concerned, spermatozoa filling the receptaculum, surrounding the opening of its duct into the pallial oviduct and concentrated along the ciliated gutter which connects the opening with the genital aperture. Perhaps the penis 
discharges the spermatozoa into the ventral gutter and then they make their own way to the receptaculum. In the animal acting as male only a few sperm are found in the sperm sac, which is probably merely a temporary storage place for them before they enter the penis. As in Omalogyra (Fretter, I948), the sperm must have been transferred to this sac prior to copulation, for it is difficult to see how they could get there after the penis has been everted.

The egg masses of Odostomia spp. are laid in irregularly shaped heaps in the vicinity of the animals upon which they feed. The spawn of $O$. rissoides is described by Pelseneer (1914) and a later account is given by Rasmussen

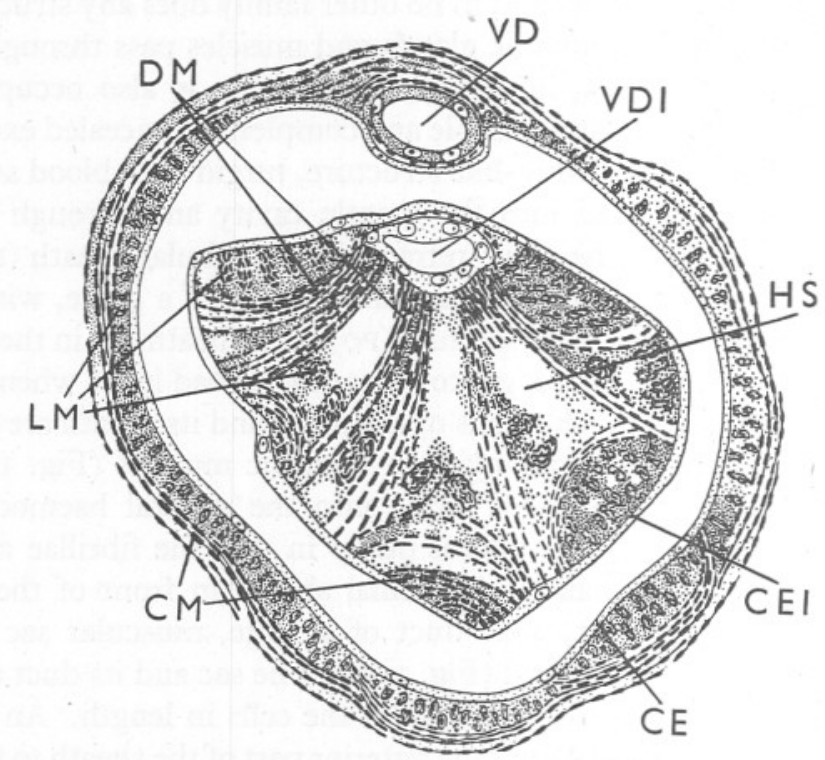

Fig. I2. Odostomia. Transverse section of penis in sheath. $\times 600 . \mathrm{CE}$, epithelium of penial sheath; CEI, epithelium of penis; CM, circular muscles; DM, dilator muscles; HS, blood spaces; LM, longitudinal muscles; VD, vas deferens in penial sheath; VD I, vas deferens in penis.

(1944), who shows that each egg is surrounded by a layer of granular albumen which is, in turn, encased in a mucous envelope or capsule. Between one egg and the next the mucous layer narrows to a fine strand. In this way all the eggs in a mass, which, according to Rasmussen (1944), may amount to five hundred, are linked into a continuous chain and then are still further surrounded and cemented together by a second and more plentiful layer of mucus, the outermost covering of the spawn, by means of which it is fixed to the substratum. An examination of the egg masses of $O$. plicata and $O$. eulimoides shows that they have a similar construction; thus they agree in general plan with those of the opisthobranch Onchidella celtica (Fretter, 1943). The staining reactions of the secretions which surround the eggs suggest the origin of these from the three glands attached to the hermaphrodite duct-the albumen gland and the 
upper and lower mucous glands-and the relative size of these is indicative of the volume of secretion produced by each in a single egg mass. The lower and larger mucous gland supplies the ample outer jelly and the upper one the capsule wall which encloses each egg with its supply of albumen and separates it from its neighbours.

The eggs are presumably fertilized in the upper part of the genital duct where sperm abound after an egg mass has been deposited, many of these superfluous spermatozoa becoming entangled in the egg coverings. The developing veliger gradually uses up the albumen as food, and in Odostomia eulimoides its development to a free larval stage, when kept at a temperature of about $18^{\circ} \mathrm{C}$., may be completed within IO-I2 days.

Lebour (1932) describes the free veliger of this species with its mobile, bilobed velum, eyes far apart, the transparency of the tissues displaying the relatively large stomach, long intestine and bilobed digestive gland. The general arrangement conforms with that of a typical gastropod veliger, for as yet no adult specialization is apparent; these first appear in the buccal and oesophageal regions of the late veliger. Lebour (I932) suggests that the larval life is short; this suggestion is supported by Thorson (1946) and has now been confirmed by actual observation: the free-swimming larval life lasts from 3 to 4 days, the larvae then becoming benthic and the metamorphosis of the gut rapidly achieved. In the metamorphosing larva the long introvert with its papillated surface, the stylet, the buccal pump and the large salivary glands may all be distinguished, and during further growth the intestine becomes relatively shorter, whilst the stomach is incorporated into the digestive gland. The eyes are now close together as in the adult. The penis, however, is not yet developed, so that the gut is the only tube passing through the nerve ring.

The eggs of $O$. plicata can be distinguished from those of $O$. eulimoides by their yellow pigmentation. They are laid in crevices of stones or rocks where the adults live. The veliger is freed from the capsule in about a fortnight and its structure agrees with that of $O$. eulimoides and $O$. rissoides (Rasmussen, I944). Thorson (I946) suggests that according to the appearance of the larval shell the free veliger life of this species is longer than that of O. eulimoides, but the exact time has not been estimated.

\section{THE PROCESS OF FEEDING}

The process of feeding has been watched in several species of OdostomiaO. lukisii, O. unidentata, O. scalaris-as well as in Chrysallida spiralis, and as the structure of the gut appears to show very little variation throughout the family Pyramidellidae it is probable that the process is similar in all species.

Chrysallida spiralis may be found sitting on the sandy tubes which are inhabited by the polychaete worm Sabellaria. When not feeding the mollusc will lurk in any little hollows in the irregular sandy mass which colonies of this 
worm manufacture, but when they desire to feed they perch themselves close to the opening through which the head of the worm will protrude. For long periods of time they may be seen sitting in this position, the head and foot out of the shell, the tentacles held upwards and forwards, facing the opening of the worm's tube. Gurrents produced by the cilia on these bring water streaming to the head of the mollusc from the region of the opening in the tube and it is probable that the mollusc is in this way made aware not only of the presence of a tube, but of the extension or otherwise of the worm that dwells within. When the polychaete cautiously emerges from its tube, however, and starts spreading its tentacles over the surroundings in order to pick up food particles then the mollusc may also start to feed: the proboscis is everted, gradually rolling outwards from the mouth till it forms a long narrow cylinder tapering gently to the sucker at its tip. The basal covering, near the tentacles, tends to be smooth, whereas nearer the sucker the peculiar papillae that lie in the epithelium give it a villous appearance. The whole proboscis can be gently waved about in the water, and the mollusc moves it slowly and delicately up to the neighbourhood of the tentacles of the worm, until actual contact is achieved. This is obviously made as quietly as may be, but the first time that it occurs the worm will usually jerk slightly, though it will not withdraw completely into its tube. The proboscis insinuates itself gently between the tentacles until it lies on their median face; there, still elongating, it slides down the ciliated groove that runs along a tentacle towards the mouth, into which its tip disappears. At this stage the proboscis is enormously elongated and as it is almost transparent the whole of the anterior end of the alimentary canal may be seen lying within. The oral tube, buccal pump and salivary glands occupy the distal half or thereabouts and from them the oesophagus runs as a narrow tube through the basal part of the proboscis until it disappears out of sight into the denser tissue of the main part of the body of the mollusc. As the buccal pump can be seen working and waves of peristalsis passing along the gut it is clear that the mollusc is sucking food into the alimentary canal, but as the tip of the proboscis is invisible, hidden inside the gut of the polychaete, it still remains uncertain what the source of the food may be and, of more interest, what exactly the stylet is doing during the process.

This, however, may be made out with certainty if other pyramidellids, like Odostomia lukisii or O. unidentata be examined. Both of these species are to be found on stones on which the tubicolous polychaete worm Pomatoceros is living, and they may be found lurking at the mouth of the tubes of these just as Chrysallida spiralis does near the mouth of Sabellaria tubes. When a Pomatoceros has expanded its crown of branchial filaments it may be observed that a nearby Odostomia will then project its proboscis towards the worm. As the proboscis moves nearer the worm it often rotates in a spiral as if it were carrying out exploratory movements, and, as before, the final approach to the filament of the worm is made apparently with as great delicacy as possible 
so as to disturb the prey as little as may be. When it is recalled that these delicate movements are carried out by a proboscis that extends to a length many times that of the rest of the animal the efficiency of the muscular control will be realized. On first contact the polychaete may jerk its crown of filaments away from the proboscis, or even withdraw into its tube altogether, and if this movement on its part is at all sudden a corresponding partial or total withdrawal of the proboscis of the mollusc will take place. Sooner or later, however, the proboscis will be extended once more, and it has been noted on several occasions with what remarkable accuracy the proboscis will reach out to the exact spot with which contact with the filament was previously made, as if the mollusc had some exact kind of kinaesthetic 'memory'. When contact is finally permitted by the worm the sucker at the tip of the proboscis of the mollusc is slid gently along the tentacle until, presumably, a suitable spot is found, usually on the outer side of the filament. Then suddenly the sucker grips the epithelium of the filament, and the stylet may be seen to drive outwards so that it is clearly being used to perforate the body of the worm. Vigorous pumping movements of the buccal apparatus may then be seen and it is obvious that fluid, blood and, perhaps, cells loosened from the worm are being sucked into the gut of the pyramidellid. The polychaete clearly feels the movements of the proboscis and the stabbing of the stylet in most cases, but worms have been observed which allowed the proboscis to move amongst the branchial crown and to slide up and down the filaments and feed in this way without any very pronounced reaction, though it must be remembered that the mollusc always appears to perform these movements with the very greatest caution.

The grip which the pyramidellid obtains on its prey is fairly secure; at least moderate movements of the branchial crown of the polychaete do not dislodge the sucker: it requires a sudden withdrawal to effect this, though we have not been able to avoid the conclusion that the mollusc then lets go, as if to avoid any danger of the proboscis being pulled into the tube and trapped or damaged in any way.

As the differences which have been found to exist between the alimentary canals of the various pyramidellids are confined to apparently unimportant details it would seem that all these animals feed in the same general sort of way.

\section{Discussion}

Apart from a few instances the Pyramidellidae are a group of gastropods little mentioned in the literature of malacology, though what has been said has tantalizingly indicated that the group would be of extreme interest were more known about its ways of life. Thus the work of Jeffreys (1867), Pelseneer (I9I4) and Rasmussen (1944) had suggested that the animals are epizoic in their habit, without making it completely clear whether their association with other animals was confined to using their shell as a home, or to picking up, using their proboscis as a pipette, mucus and other secretions from the body of the animal on 
which they lived, or whether they were indeed true ectoparasites and fed on the body of a host. That some such idea was in the minds of most malacologists is probable, since the Pyramidellidae were associated by Thiele (I929) with the families Melanellidae (=Eulimidae), Stiliferidae and Entoconchidae in the stirps Aglossa, all these families containing animals known to be parasitic in their mode of life. Winckworth (1932), too, places these families side by side, although he refrains from uniting them more closely by avoiding all grouping within the order Mesogastropoda.

The description which has been given above, however, makes it quite plain that the pyramidellids are ectoparasites, and that they live on the blood and perhaps tissue débris of other animals on which, or in the neighbourhood of which, the mollusc passes the greater part of its life. Each species of pyramidellid appears to be associated with one definite host, and as might be expected these are, so far as is known, sessile organisms which are easily found, and which must, if they are to survive at all, from time to time protrude some part of their body for the collection of food, and so make it available simultaneously to the gastropod. The list of hosts which has so far been gathered definitely is:
Chrysallida spiralis ... Sabellaria spp.
Odostomia unidentata ... Pomatoceros triqueter
O. lukisii $\quad$... $\quad$... Pomatoceros triqueter
O. scalaris $\quad \ldots \quad \ldots \quad$ Mytilus edulis (small only)
O. eulimoides $\quad . . . \quad \ldots$ Pecten maximus and Chlamys opercularis
O. trifida $\quad \ldots \quad \ldots$ Mya arenaria
Turbonilla jeffreysii ... some coelenterate, probably Halecium sp.

These species of pyramidellid will be found, with surprising abundance, as they are not really uncommon animals, in the vicinity of the particular host upon which they feed. They will be found to feed on no other animal. At Plymouth, Turbonilla jeffreysii may be dredged from the localities where the hydroid Halecium abounds, and that the mollusc is in fact feeding upon it is suggested by the occurrence of masses of nematocysts in the cells of the innermost part of the oesophageal epithelium, which are similar in size to those in the cells of the hydroid. Actual feeding has not, however, been observed in this species. Another species of Odostomia, O. plicata, is to be found in association with Pomatoceros, occurring, in the Plymouth district, at a lower level on the beach than Odostomia unidentata and O. lukisii. It feeds less willingly when kept in captivity and thrusts its proboscis out at a variety of creatures-even on to the antennae of living amphipods. On two occasions sponge spicules have been found in its gut, suggesting that this species may suck the tissues of a sponge. Although the nature of the mode of life of pyramidellids has been verified for a mere handful of the forty-odd species listed by Winckworth (I932), the gut is of such homogenous structure in all the species that have been investigated, that there is little doubt that they all live in the same general 
fashion and that further work will lead to the discovery of the correct host for each species. Until this is known no search for a given kind of pyramidellid can be productive, and the old records of habitat given by Jeffreys (I867) or Forbes \& Hanley (I853), such as 'under stones', 'on corallines in rock pools', etc., are valueless as indications as to where the animals really live. When the host is known success in collecting can usually be relied upon.

There are a few clues in the literature regarding hosts of some of the species for which they are not yet known: Marshall (I900) notes the occurrence of Turbonilla rufescens on 'the leathery tube of a sessile annelid' and of 'dwarf specimens of Odostomia albella with littorinae'. Gardiner (I934) mentions the occurrence of $O$. perezi Dautzenberg and Fischer with Phascolion strombi.

The alimentary canal of the various pyramidellids which have been examined varies from species to species only in the very slightest way: the stylet is short in some (Odostomia eulimoides), longer in others; there is a separate stylet tube and oral tube in Chrysallida and Odostomia, whereas in Turbonilla there is but the one tube along the centre of which the stylet runs; the papillation of the introvert is pronounced in Odostomia unidentata and O. plicata, less so in $O$. lukisii and Chrysallida spiralis, and is hardly indicated in Turbonilla; the salivary glands are better developed in $T$. jeffreysii than in the other genera-perhaps in connexion with the habit of that species of feeding on coelenterates, where a copious salivary secretion might have a special significance in desensitizing the nematocysts (Pantin, I942). Apart from these relatively unimportant details the gut is very similar throughout the family, and the interest in it lies, not in the variation from species to species, but in trying to homologize the very specialized arrangement found here with the more typical gastropod plan. Practically all the specialization lies in the anterior end of the gut. From the region of the buccal pump onwards the general plan of the gut does not depart significantly from what might be expected-an oesophagus runs back to a stomach and from there an intestine passes to the mantle cavity. The stomach is extremely simple, and is clearly just a place where oesophagus, digestive gland and intestine join, but that is no more than might be expected in animals of such small size feeding on a simple diet (see Fretter, I948).

The main interest centres in the homologies of the anterior region and two structures may be used as guides to the correct interpretation of these: the salivary ducts and the labial ganglia. In the typical gastropod mollusc the mouth opens by a short oral tube into the buccal cavity. On the floor of the buccal cavity is placed the odontophore and along its roof runs the anterior end of the dorsal food channel, separated from the more lateral portions of the cavity by extensions of the dorsal folds. External to the roof of the cavity lie the salivary glands. Their ducts run in connective tissue, one at the base of each dorsal fold, and open into the buccal cavity dorsolaterally, near its anterior end, about the level at which the dorsal folds end. Anterior to this part the roof of the buccal cavity slopes ventrally into the dorsal wall of the oral tube and it is 
in this region that a jaw, or jaws, will be developed, should the animal possess such structures. These arise as cuticular growths from the epithelium covering the dorsolateral wall of the buccal cavity and oral tube. Often the lateral parts, and, always, the anterior end of the jaws are lifted off the epithelium upon which they have been produced so that they project freely into the buccal cavity anterior to the apertures of the salivary ducts. Now, were the two salivary ducts to run together so as to open into the roof of the buccal cavity on a median papilla and were this then to elongate and grow forwards, it would rapidly reach the level of the jaws, and if the free edges of these structures were further supposed to grow ventrally around the salivary duct in its new position a chitinous tube would have been produced, attached dorsolaterally to the epithelium of the buccal cavity at its inner end, but free anteriorly, and this would surround a tube formed from the fusion of the two ducts of the salivary glands. In other words, the condition exhibited by the pyramidellids would have been attained. That the cuticular stylet is, indeed, dorsal, is further shown by the position of the labial ganglia, which lie on the opposite side of the oral tube at the level of the mouth, and by the buccal ganglia which are likewise placed ventral to the apparatus. These relations by themselves would indicate that nothing in the present arrangement could correspond to a radula, a structure which normally lies ventral to the buccal commissure. The glands lying in the oral tube and buccal cavity in the pyramidellids would correspond to the mucous glands which lie scattered over the buccal cavity of other gastropods, more especially in its dorsal part. Nothing comparable to dorsal folds or dorsal food channel seems to occur in the pyramidellids, however: the innermost part of the buccal cavity seems to have become specialized along completely different lines to produce the buccal bulb, whilst the oesophagus is a simple, elongated crop-like structure without any of the characteristic glandular areas of the typical prosobranch.

In Turbonilla a single aperture on the sucker leads into a simple oral tube in which the stylet lies (Fig. 5); in Chrysallida and Odostomia (Figs. I, 3 and 4) the sucker has a ventral mouth and a dorsal stylet aperture, and two tubes lie parallel to one another in this portion of the gut. How may these have arisen? The probable explanation is to be seen in the occurrence, in a gastropod like Patella, of a pair of inner lips (Graham, 1932, Fig. I). These are attached to the lateral walls of the oral tube, ventral to the jaws, and they may be moved across the oral tube from side to mid-line so as to act like a curtain, dividing the tube into a dorsal half into which the jaw projects, and a ventral half which would be separated from the part in which the jaws lay. Were this contiguity to become a fusion, and were the base of the jaws to abut on, or fuse to, the base of the fold, then precisely the situation which is exhibited in Chrysallida and Odostomia would have arisen. In this way stylet aperture and apparent mouth may be shown to be merely parts of the original mouth, and the stylet tube a separated portion of the original oral tube. 
The evolution of a long proboscis is clearly a necessary feature in the particular feeding habits that the pyramidellids have adopted, and this has apparently involved the penis as well, so as to give rise to the peculiar arrangement by which the sheath of that organ lies within the nerve ring ventral to the oesophagus. In the typical gastropod the mouth lies ventral to the tentacles and the penis is placed on the right-hand side of the head behind and below the right tentacle. An acrembolic proboscis is produced by an elongation of the tip of the snout, anterior to the tentacles, so that the mouth comes to be placed at the summit of a long pretentacular extension, which is everted and appears as such only when the creature is feeding. At other times it is withdrawn and a 'mouth' - though not the true mouth-lies in the usual position. Now suppose that the elongation occurs behind the penis: that will then lie near the tip of the proboscis when elongated and would be carried into the introvert when the proboscis was withdrawn, and the ciliated groove running along the right side of the head from the genital opening to the penis would appear to end at the mouth of the introvert. This consequence of the production in this particular way of a long proboscis produces unnecessary complexities in the functioning of the reproductive apparatus, and it would be needful to suppose that the penis, now brought far inside the body by its association with the introvert, has gradually separated itself from the introvert, and that its external opening has migrated forwards along the ventral wall of the introvert until it finally reached the surface of the body once again. This migration forwards of the opening of the penis gives rise to a long tube, the penial sheath, which, as it has been formed by separation from the introvert, must penetrate the nerve ring, and which will open to the exterior near the mouth. The mentum must have arisen after this migration has taken place, since it separates mouth and penial opening, and it is, therefore, a novel structure without any deeper significance, perhaps, than a barrier between these two apertures. It is tempting to think that the original cephalic tentacles of the ancestral pyramidellid were also involved in the formation of the introvert and have been lost and replaced by new structures, which would explain the peculiar shape of these and the fact that the eyes lie on their inner instead of their outer sides. But this position may merely be the result of a direct migration such as occurs during development (Lebour, I932).

The bulk of the digestive processes appear to go on inside the digestive gland, the oesophagus acting primarily as a crop. Whether the peculiar lining of the introvert has any digestive significance or not we are unable to say, but it is interesting to note that various particles of detritus, diatoms and such like, are sometimes to be found inside the retracted introvert: this is probably merely accidental contamination in view of the fact that its surface is probably sticky from the secretion of the numerous glands placed there. The precise function of these remains obscure. As they are most abundant in the neighbourhood of the sucker and least near the base of the proboscis it would seem likely that 
they are concerned with the process of feeding, as it is precisely the part of the proboscis which comes most into contact with the body of the prey which carries the greatest number of glands. They therefore most probably lubricate the movement of the proboscis so as to make it less likely of notice by the prey.

The second main point to which attention must be directed is the systematic position of the family Pyramidellidae. Although from the time of Mørch (I865) suggestions have been put forward that the family, if not actually opisthobranch, may be the group of prosobranchs from which the opisthobranchs originated, they have always in fact been classified as prosobranchs, usually associated with other groups of known or suspected similar feeding habitsexplicitly or implicitly in an aglossan grouping. It is true that the pyramidellids resemble, for example, the Eulimidae and Stiliferidae in having lost the radula, but the most cursory examination of a eulimid (our own unpublished observations) or stiliferid (Kœhler \& Vaney, I908) shows that otherwise there are few points of agreement between the two families. The Eulimidae and the Stiliferidae are certainly extremely specialized in connexion with their ectoparasitic habit, but this has taken place along completely different lines from the Pyramidellidae.

The question as to the true systematic position of this family has lately been raised again by Thorson (1946), who points out that the characteristically heterostrophic larval shell of the pyramidellids is a feature which they share with a large number of opisthobranchs. On the basis of the work described in the preceding pages a comparison of pyramidellids and other gastropods may now be extended to other systems and the classification of the family reviewed in the light of the results of this.

In so far as the pyramidellids have a spirally coiled calcareous shell into which the entire body is retractible, a foot bearing an operculum, and a large anteriorly directed mantle cavity they resemble the prosobranchs. The same holds for the occurrence of a long proboscis. But when these things have been pointed out then almost all the specifically prosobranch characteristics of the animals have been mentioned. The various other ways in which the body of a pyramidellid differs from that of a typical prosobranch may be due $(a)$ to specialization in connexion with its ectoparasitic life, or $(b)$ to the fact that it is small and may therefore be secondarily simplified, or $(c)$ to the fact that it is really an opisthobranch. In relation to the third possibility it is well to recollect that opisthobranchs like Actaeon may have spirally wound calcareous shells into which the body may be withdrawn and which can be closed by an operculum, and that they may have an anteriorly directed mantle cavity and be streptoneurous, so that the fact that the pyramidellids have the characteristically prosobranch features enumerated above does not debar them from being opisthobranchs.

So far as external features are concerned the contents of the mantle cavity first call for attention. Here no ctenidium is developed: this may be due to 
small size, as in Omalogyra (Fretter, I948), but it is noteworthy that in the family Actaeonidae the gill is reduced to a single triangular leaflet, whilst the main current of water is maintained within the mantle cavity by strips of ciliated epithelium as in Odostomia. As Fretter (I948) has suggested, in connexion with another group of gastropods, the forward projection of the kidney into the mantle may be valuable for the sake of the capillary bed which migrates with it: this feature also occurs in pyramidellids and in Actaeon. In another family of opisthobranchs, too, the Diaphanidae, the mantle resembles that of the Pyramidellidae in containing a dark brown-red gland of unknown significance. The mantle edge on the right side has a small lobe-like projection in pyramidellids: the actaeonids and hydatinids amongst the opisthobranchs have a similar process, although it is there larger and glandular. The tentacles carried on the head of a pyramidellid are ear-shaped: those on the head of the opisthobranchiate Hydatinidae are similar; the eyes are placed on their median sides on both groups, and in many other opisthobranchs that is also the position in which they are found, although there they are often sunk below the surface, a tendency not noticeable in the pyramidellids, unless convergence towards the mid-line is the first stage towards such a position.

In the construction of the alimentary canal there are several points in which pyramidellids and opisthobranchs agree: the complete suppression of the oesophageal glands and dorsal food channel (Graham, I939); the tendency for the oesophagus to form a crop-like expansion and for the stomach to be merely a space into which the ducts of the digestive gland discharge (Graham, I949); the shortness of the intestine; the tendency for the digestive cells of the digestive gland to become laden with spherules (Fretter, I939)—all these are characteristics of opisthobranchs in general. There are one or two points in which the pyramidellids show similarity to special groups of the opisthobranchs and these groups are, as observed in the discussion of the external features, the most primitive families. In the hydatinids, for example, Thiele (I93I) notes that the oral tube is very long, and it is well known that in the Actaeonidae the radula carries only extremely small and weak teeth, a characteristic also encountered in other groups of primitive tectibranchs. In other points the anatomy of the pyramidellid alimentary canal is much specialized, as is only to be expected in view of the parasitic mode of life which the group has adopted, but even here it may be noted that the buccal pump may be paralleled in the ascoglossans (Fretter, I940).

It is rather difficult to use the nervous system of the Pyramidellidae as a clue to the relationship of the family, as it is possible for prosobranchs to be euthyneurous and for opisthobranchs to be streptoneurous. Of greater importance, perhaps, is the degree of concentration of the ganglia towards the formation of a nerve ring, and in this connexion the pyramidellids show a clear trend towards the opisthobranchiate condition. Pelseneer (1899) attempted to refute Mørch's original suggestion that the Pyramidellidae were opistho- 
branchs on the grounds that the cerebral ganglia, like the pedal, were so close together that they were practically fused with one another, that the nerve ring was not anterior to the salivary glands and that the statocyst contained only one statolith-all points on which they differed from the 'Bulléens'. The first of these characteristics, however, is by no means unknown in the Opisthobranchia, while the second may very well have arisen in relation to the extreme specialization which the anterior end of the gut has undergone.

Further evidence bearing on the relationships of the family is provided by the reproductive system, and in this, as in the alimentary system, there are several points in respect of which pyramidellids resemble opisthobranchs rather than prosobranchs: the gonad is hermaphrodite, not unisexual; the ova receive their albuminous covering as they pass along the sperm-oviduct and do not enter the albumen gland (Fretter, I946); large mucous glands provide a jelly which forms the outer, protective covering of the egg mass and there is neither capsule wall nor pedal gland to mould it; an open seminal grove leads from the common genital aperture to the penis, which is invaginable; a sperm sac is attached to the penial sheath and is filled with spermatozoa before each copulation; the veliger has a sinistral shell. The closest agreement is with the more primitive families of the tectibranchs, in which the genital duct is monaulic and male and female apertures lie at some distance from each other. Except for minor variations in proportion the penis and its sheath agree in general plan and in histology with those of Philine aperta (Pruvot-Fol, I930): when the penis is extended a flow of sperm into it is rendered impossible by the arrangement of the ducts and a reservoir or sperm sac is therefore required.

Finally, it is to be noted from the conchological side, that the tooth on the columella-from the presence of which the genus Odostomia acquires its name - so characteristic of the Pyramidellidae, is also to be met with in the Actaeonidae, Ringiculidae and Diaphanidae amongst the tectibranchs.

If all these points be taken into consideration there is such a large number of characters in which the resemblance between the family Pyramidellidae and the Opisthobranchia is marked that it seems logical to remove the family from the subclass Prosobranchia to the subclass Opisthobranchia. ${ }^{3}$ As to the precise position within the Opisthobranchia that the Pyramidellidae should occupy there is some doubt, because of our lack of knowledge of the soft parts of such opisthobranchs as Actaeon, Hydatina, Diaphana and Haminea, and, until such animals have been properly investigated, any assignation of the Pyramidellidae to a definite position must be tentative. In view of their stout, spiral shell and operculum, however, they are more primitive than all the opisthobranchiate families other than the Actaeonidae; because of their euthyneurous nervous system and loss of ctenidium they are more advanced than

1 Owing to a misprint we appear (Fretter \& Graham, I949) to have said precisely the reverse of this in a letter to Nature. 
that family but less than the Diaphanidae. Until more is known of the anatomy of these two families of the opisthobranchs the family Pyramidellidae may be placed between them.

The Pyramidellidae is not the only family of gastropods superficially prosobranch in appearance but probably opisthobranch in reality. The Omalogyridae, in which Omalogyra has been recently described (Fretter, 1948)-and from a preliminary study Ammonicera would seem to agree-have also an imposing assemblage of characters in common with the opisthobranchs: the animals are hermaphrodite; the penis is a long, whip-like muscular tube into which, during copulation, sperm are passed from a sac; there are no oesophageal glands; the stomach is simplified and is merely a space within the digestive gland; the intestine is short; large and histologically complex glands open into the mantle cavity, which is without a ctenidium but has strips of ciliated epithelium running forwards from the anus to maintain an exhalant flow of water. Unlike the opisthobranchs, but like most prosobranchs, the Omalogyridae produce egg capsules. It is uncertain to which group of the opisthobranchs these minute gastropods should be allied, for our present knowledge of the opisthobranchs is particularly poor so far as the most primitive members of the subclass are concerned-and these are the very ones involved.

\section{SUMMARY}

The family Pyramidellidae contains a number of species of gastropod molluscs of similar structure and mode of life.

The shell is calcareous and spirally wound and may be closed by an operculum. The foot bears a transverse fold anteriorly, the mentum (Fig. I, MT), separating the opening of the penial sheath (PO) below from the mouth (M) above. It has a lateral glandular streak on each side (Fig. 2), presumably sensory.

The head has ear-shaped tentacles (Fig. I, T), richly innervated and with cilia setting up a strong water current, so that they constitute a powerful sensory mechanism. The eyes (E) lie between the tentacles.

The mantle cavity faces anteriorly, is wide and deep. To it open the anus, at its inner end; the kidney, on its roof; and the single genital aperture, on its floor. There is neither ctenidium nor osphradium, but well-developed hypobranchial and other glandular fields. A circulation of water is maintained by strips of ciliated epithelium in relation to these. A special pigmented structure, perhaps glandular, lies by the genital aperture and a ciliated tract leads from there to the opening of the penial sheath.

The 'mouth' leads to a long introvert with a specially glandular papillated epithelium (Fig. I, EP; Fig. 8, EPL, EPT). At the inner end of this the true mouth (Figs. I and 4, M) lies on a sucker (Fig. 4, MCS, MOS) and an elongated oral tube (OT) leads to the buccal cavity. From a dorsal pouch of this (Figs. I and 3, DP) 
a long stylet projects forwards (s), in a separate tube in Chrysallida and Odostomia but in the main oral tube in Turbonilla, and may be thrust outwards from the sucker. The stylet encloses the common duct of a pair of salivary glands (Fig. 3, USD). The posterior part of the buccal cavity is differentiated into a double muscular sac, the buccal pump (Fig. I, BP), and the walls of this, the salivary ducts and sucker contain striped muscle fibres. From the buccal pump the oesophagus (o) runs to the stomach and digestive gland and thence a short intestine passes to the anus. There is no radula.

In the vascular system only a posterior aorta leaves the heart. The anterior aorta arises from the visceral haemocoel. Blood cells, active as excretory amoebocytes, are common.

The nervous system (Fig. Io) is mainly concentrated into a ring round the oesophagus and penial sheath and is euthyneurous. An osphradial ganglion (OG) lies in the mantle on the left and two pairs of ganglia lie ventrally in relation to the anterior end of the gut: these are the buccal ganglia (Fig. I, BG), close to the buccal pump, and the labial ganglia (LC) in relation to the sucker.

The gonad is hermaphrodite (Fig. II, H) and from it a narrow duct passes towards the mantle cavity (GD), receiving on its way ducts from the albumen gland (AG, DA) and proximal (MGU, DU) and distal (MGL, OL) mucous glands. Opposite the opening of the latter arises the duct of the receptaculum seminis (RS). The initial part of the broad pallial duct is glandular (GO) and is probably a prostate. From the common genital aperture in the mantle cavity an open seminal groove leads to the invaginable penis (Fig. I, Po). A sperm sac is attached to the penial sheath (ss) and is filled before each copulation.

The eggs, each surrounded by albumen and enclosed in a mucous sheath which is continuous from one egg to the next, are embedded in secretion from the distal mucous gland and deposited in irregularly shaped clumps near the feeding grounds of the adult. The veliger is characterized by the sinistral shell and the pigmented gland on the right side of the mantle. Its oesophagus, intestine and commodious stomach, into which opens the bilobed digestive gland, are greatly modified during metamorphosis at the end of pelagic larval life.

Pyramidellids are ectoparasites. Each species feeds on a particular species of host, usually a tubicolous polychaete or a lamellibranch mollusc, obtaining attachment to the body by means of the oral sucker, piercing the body wall with the buccal stylet and sucking blood, and perhaps tissue débris, by means of the buccal pump.

A consideration of the structure and reproductive habits of the group leads to the conclusion that they are opisthobranchiate gastropods. 


\section{REFERENCES}

Ankel, W. E., 1936. Prosobranchia in: Grimpe, G. and Wagler, E., Die Tierwelt der Nord- und Ostsee, Teil $\mathrm{Ix} b$. Leipzig. $240 \mathrm{pp}$.

- 1938. Erwerb und Aufnahme der Nahrung bei den Gastropoden. Verh. dtsch. Zool. Ges., Zool. Anz., Suppl. xI, pp. 223-95.

Forbes, E. \& Hanley, S., I853. British Mollusca. London.

FRETTER, V., I939. The structure and function of the alimentary canal of some tectibranch molluscs, with a note on excretion. Trans. Roy. Soc. Edin., Vol. LIX, pp. 599-646.

- 1940. On the structure of the gut of the ascoglossan nudibranchs. Proc. Zool. Soc. London, B, Vol. cx, pp. 185-98.

FRETTER, V., I943. Studies in the functional morphology and embryology of Onchidella celtica (Forbes \& Hanley) and their bearing on its relationships. Fourn. Mar. Biol. Assoc., Vol. xxv, pp. 685-720.

- 1946. The genital ducts of Theodoxus, Lamellaria and Trivia, and a discussion on their evolution in the prosobranchs. Fourn. Mar. Biol. Assoc., Vol. xxvI, pp. 312-5I.

- 1948. The structure and life history of some minute prosobranchs of rock pools: Skeneopsis planorbis (Fabricius), Omalogyra atomus (Philippi), Rissoella diaphana (Alder) and Rissoella opalina (Jeffreys). Fourn. Mar. Biol. Assoc., Vol. xxvII, pp. 597-632.

Fretter, V. \& Graham, A., I949. Feeding and reproduction in the pyramidellids. Nature, London, Vol. cLXIII, pp. 36I-2.

GardineR, A. P., I934. The littoral zone. Fourn. Conch. Vol. xx, pp. 65-76.

GRAHAM, A., I932. On the structure and function of the alimentary canal of the limpet. Trans. Roy. Soc. Edin., Vol. LvII, pp. 287-308.

- 1939. On the structure of the alimentary canal of style-bearing prosobranchs. Proc. Zool. Soc. London, B, Vol. crx, pp. 75-II2.

— 1949. The molluscan stomach. Trans. Roy. Soc. Edin., Vol. LxI, pp. 737-78.

Jefrreys, J. G., I867. British Conchology, Vol. Iv. 486 pp. London.

KøehleR, R. \& VANEY, C., I908. Description d'un nouveau genre de Prosobranches parasite sur certains Echinides. (Pelseneeria nov.gen.). Bull. Inst. océanogr. Monaco. no. II 8 , pp. I-I6.

Lebour, M. V., I932. The eggs and early larvae of two commensal gastropods, Stilifer stylifer and Odostomia eulimoides. Fourn. Mar. Biol. Assoc., Vol. xviII, pp. II7-22.

Marine Biological Association, 1931. Plymouth Marine Fauna. (2nd. ed.) Plymouth.

Marshall, J. T., I900. Additions to 'British Conchology'. Fourn. Conch. Vol. IX, pp. 284-96.

MedCoF, J. C., I948. A snail commensal with the soft-shell clam. Fourn. Fish. Res. Board Canada, Vol. vir. [Not seen.]

MørCH, O. A. L., I865. On the systematic value of the organs employed in the classification of Molluscs. Ann. Mag. Nat. Hist., ser. 3, Vol. xvi, pp. 385-97.

Pantin, C. F. A., I942. The excitation of nematocysts. Fourn. Exp. Biol., Vol. xix, pp. 294-310.

PelsENeER, P., I899. Recherches morphologiques et phylogénétiques sur les mollusques archaiques. Mém. cour. Mém. Sav. étr., Acad. Roy. Belg., Vol. LvII, pp. I-I I2.

— I9I4. Ethologie de quelques Odostomia et d'un Monstrillide parasite de l'un d'eux. Bull. Sci. France Belgique, sér. 7, Vol. xLvIII, pp. I-I4.

Pruvot-Fol, A., I930. L'appareil copulateur de la Philine et du Notarchus. Arch. Zool. Exp. Gén., T. Lxx, pp. 45-5I. 
RASMUSSEN, E., I944. Faunistic and biological notes on marine invertebrates. I. Vidensk. Medd. naturh. Foren. Kbh., Bd. cvII, pp. 207-I5.

ThIEle, J., 1929. Handbuch der systematischen. Weichtierkunde. Teil I. Jena. I93I. Handbuch der systematischen Weichtierkunde. Teil. II. Jena.

Thorson, G., I946. Reproduction and larval development of Danish marine bottom invertebrates. Medd. Komm. Havundersog., Kbh., ser. Plankton. Bd. Iv, pp. I-523.

YoNGE, C. M., I947. The pallial organs in the aspidobranch Gastropoda and their evolution throughout the Mollusca. Phil. Trans. Roy. Soc. London, B, Vol. CCXXxII, pp. 443-5I8.

Winckworth, R., I932. The British marine Mollusca. Fourn. Conch., Vol. xIx, pp. $2 \mathrm{II}-52$. 